\title{
ECONOMICS
}

\section{JAPAN'S ECONOMIC SLOWDOWN AND ITS GLOBAL IMPLICATIONS: A REVIEW OF THE ECONOMIC MODELLING}

by

Rod Tyers

Business School University of Western Australia

and

Jenny Corbett

Crawford School of Economics and Government Australian National University and St Antony's College Oxford 


\title{
JAPAN'S ECONOMIC SLOWDOWN AND ITS GLOBAL IMPLICATIONS: \\ A REVIEW OF THE ECONOMIC MODELLING*
}

\author{
Rod Tyers \\ Business School \\ University of Western Australia and \\ College of Business and Economics \\ Australian National University \\ Jenny Corbett \\ Crawford School of Economics and Government \\ Australian National University and \\ St Antony's College, Oxford
}

First revision November 2011

Key words:

Japanese economy, economic growth, demographic change, productivity, real

exchange rate

DISCUSSION PAPER 11.19

\begin{abstract}
Despite its role as a driver of global economic growth through the 1970s, in recent decades the rise of China has seen the international importance of Japan's economic performance recede from the public discourse. This is notwithstanding its continuing key role as economic partner to both industrial and developing countries and changes in its economic performance that would otherwise be a matter for global concern. In particular, the tendency for the Japanese economy and its external trade to stagnate not only has immediate consequences for global performance but it also foreshadows a path to industrial transition for other key Asian economies. This paper reviews quantitative studies of Japan's performance. It identifies a paucity of results addressing global implications and suggests new research in this direction.
\end{abstract}

\footnotetext{
* For advice and useful discussions we thank our colleagues Warwick McKibbin and Aki Asano and for extensive research assistance, thanks are due to Yong-Hin Lim, Luke Meehan, Alan Cheong, Ying Zhang and Nagulan Siritharan.
} 


\section{Introduction}

The recent and comparatively large economic downturn in Japan following the global financial crisis drew attention to the need to understand the functioning of Japan's economy and to anticipate and quantify the global implications of these large changes in Japan's performance. In spite of recent changes in the structure of the global economy, most notably the rise of China, Japan still makes the second largest contribution to economic activity. For regional trading partners it remains a giant. In Australia, for example, it is the second largest trading partner and the second largest source of foreign investment. Changes in its performance therefore affect its trading partners directly, but there are also indirect effects, via Japan’s global economic links. Moreover, Japan's path to industrialisation after the 1980s is widely seen as foreshadowing wider global performance in the 2000s (Syed et al. 2009).

The performance of Japan's economy, and its responses to recent external shocks, present numerous conundrums. Having led global economic growth in the two decades leading up to the mid-1980s, its economy has stagnated since. Possible, though in some cases much debated, hypotheses regarding Japan's stagnation include, first, the end of the technical “catch-up” phase of Japan's development and hence an underlying slowdown in tradable productivity growth (Comin and Hobijn 2010, Hayashi and Prescott 2002) that exposed its comparatively inefficient services sector (Fukao 2010). Second, its responses to US pressure in the 1980s and 1990s, allowing substantial real appreciations against the US (McKinnon and Ohno 2001, Hamada and Okada 2009), Third, the high productivity growth in its near neighbour, China, diverting investment funds abroad; fourth, labour force contraction due to low and declining fertility and resistance to immigration (Economist 2010), and fifth, deflation and the liquidity trap since the early 1990s (Krugman 1998). Understanding the contributions and significance of each of these hypotheses is essential to assessing their implications for Japan’s trading partners.

These issues are readily addressed using economic modelling and our objective is to review the many such studies that employ quantitative modelling methods. Of course modelling methods are many and varied. The best way to assess both the determinants of Japan's performance and their inter-linkages with the global economy is to use mathematical models that quantify the relationship between economic 
variables and between countries. Individual country models can be applicable in that external relations must be represented in them at least at some level. These may be “structural”, typically drawing together the elements of the domestic macro-economy in a manner tied to economic theory and allowing "policy experiments" to be carried out by introducing "shocks" to the model. While such models, which include most in the "general equilibrium" category, identify large numbers of economic variables, they usually embody behaviours that can fail to be represented in standard macroeconomic data and so are frequently "calibrated” rather than estimated.

The general equilibrium umbrella covers a range of modelling approaches, from "real business cycle” models emphasising inter-temporal choice (Hayashi and Prescott 2002) through the common real general equilibrium models that are less sophisticated in their representation of saving behaviour (Dixon et al. 1982, Dixon and Rimmer 2002), the multi-regional and multi-sectoral models that include money and assets (McKibbin 1993) and including modern “dynamic stochastic general equilibrium (DSGE)” models (Sugo and Iwata 2008). While there is an expanding literature on estimated DSGE models that spans the traditional gulf between structural models and econometric models, pure econometric approaches are commonly less rich in their theoretical foundations but reliant more on estimation from the available data. Such studies now employ "vector auto-regression” methods that originate with Sims (1980, 1990). For the most part, the "general equilibrium" class of models are thus best adapted to analysing the effects of policy changes in one country or region on the performance of others. Yet financial shocks are represented in all the models as exogenous shifts in behavioural parameters. The genesis of financial shocks is poorly represented. There are as yet no practical models with broad application to economic policy that embody necessary behavioural finance.

Global, or multi-country models, usually consist of country modules the analytics of which resemble each other. Differences between countries then stem from numerical differences in technical parameters, mixes of products consumed and the compositions of government spending and investment. At their best, these models explicitly model the trade and sometimes capital flows between economies. They therefore allow for a sophisticated representation of the transmission of shocks between economies. Such models may emphasise country macro-economies but offer 
less detail as to trade and other microeconomic variables ${ }^{1}$, or they may be very detailed on the trade side with relatively little structure on the macro economy. ${ }^{2}$ The McKibbin "G-Cubed” suite of models offers a range of compromises between these extremes in combination with an unusually complete representation of money and asset markets. $^{3}$

Some studies have addressed the international implications of Japanese economic performance explicitly, mostly applied to examine the effects of proposed free trade agreements with Japan. There is, nonetheless, comparatively little model-based research that addresses the international implications of Japan's recent performance explicitly. This became obvious and pressing recently when the GFC caused dramatic collapses in industrial output in the export-oriented economies of Asia but a comparatively large contraction in Japan, the origins and international implications of which remain unclear.

It is timely to survey recent model-driven research and modelling approaches currently in use in business and government as a basis for assessing the determinants of Japan's apparent stagnation, how it responds to shocks and how these may be transmitted to trading partners. This is important not only for an understanding of short term business cycle effects (of which the GFC and its aftermath have been prominent examples) but also for understanding long term structural changes such as demographic shifts and the major relocation of Japan's productive capacity offshore. This paper reviews the available modelling, noting its contributions thus far and its potential for further analysis of Japanese and global economic performance. The section to follow briefly examines the coincidence of the slowdown in Japan and the rise of China, which has mitigated the global impact. Section 3 reviews hypotheses and economic debates concerning Japan's recent economic performance that have already been the subjects of considerable quantitative analysis. Section 4 then describes the evolution of modelling method and the variety of current approaches to modelling, their characteristics and their limitations, while Section 5 offers our own

\footnotetext{
${ }^{1}$ An example of a macroeconomic multi-region model is the Oxford Economic Forecasting Model widely used by numerous Treasuries and Central Banks (www.oxfordeconomics.com).

${ }^{2}$ Multi-regional models that emphasise microeconomic behavior include the GTAP group. For detailed descriptions see Hertel et al. (1998), Ianchovichina and McDougall (2000) and Ianchovichina and Walmsley (2010).

${ }^{3}$ Relevant applications of the G-Cubed suite include McKibbin (1993 and 2005).
} 
brief and illustrative modelling exercises that cover some of the hypotheses in Section 3, along with suggestions for further analysis. Section 6 briefly concludes.

\section{Japan's Performance in a Global Context}

First, it is useful to confirm that the term "stagnation” applies. The pattern of Japan's nominal and real GDP growth is shown in Figure 1. Both slowed after 1990, yet there are several reasons why stagnation might be an inappropriate term. First, the postbubble period has been deflationary and so real growth should look better than nominal. Second, following the bubble economy a return to a benchmark growth path might be expected, requiring a temporary interval of slow growth. Third, Japan’s population has stopped growing and, because it is ageing, its workforce is contracting. Performance per capita, or per worker, must surely have been better than that in aggregate. Fourth, despite its very successful manufacturing brands, Japan is now a service economy. Growth in such economies is poorly measured since, for many service industries at least, output is difficult to measure and is often recorded as merely the value of the inputs used. While no solution is offered here to the fourth of these provisos, the possibility that strong performance is disguised by a shrinking labour force is addressed in Figure 2, which shows that there was some growth in real GDP per worker, a little less in real GDP per capita and virtually none in real consumption per capita. The stagnation would therefore appear to be real so far as the available data go.

Importantly, while Japan's economy was slowing, that of its near neighbour, China, was expanding rapidly. With this "changing of the guard”, the net economic effects on trading partners were rendered less perceptible. Figure 3 shows Japan's and China's shares of global GDP, compared at market exchange rates. ${ }^{4}$ The path of their total GDP holds a stable share of global GDP by this measure, with the decline in Japan's individual share being closely matched by the rise in China's. Yet, while China’s rapid ascent has stolen the limelight, Japan’s long history of foreign investment has left it by far the dominant Asian capital owner abroad. In Australia, for example, Japan is still the dominant Asian investor with about a $20^{\text {th }}$ of the foreign

\footnotetext{
${ }^{4}$ When the shares are constructed using PPP adjustments from the Penn World Tables database, the path of China's share (version 1) shifts up two to three fold and the total grows, but the story remains the same.
} 
owned capital stock (Sanyal 2009). Moreover, the substantial increase in applications for Chinese FDI in Australia during the past decade has been more than matched by far less notorious increases in FDI from Japan. ${ }^{5}$ With economic significance on this scale Japan's stagnation has been important, not only within Japan but also globally.

\section{Economic Stories}

There are numerous English language surveys of Japan's economic dilemmas of recent decades, ranging from the very general (The Economist 2010) to the more deeply analytical (Boltho and Corbett 2000, Miyao 2006). Our purpose in this section is not to offer a survey of this vast literature but instead to summarise some economic stories concerning the Japanese slowdown that have been, or could be, addressed by research using quantitative models.

\subsection{The exhaustion of "catch-up" growth opportunities:}

According to this view, Japan's very fast expansion from the 1950s to the 1970s depended significantly on the use of technologies available from abroad. As it approached the global technical frontier, further opportunities for such growth diminished (Lincoln 1988, Saito 2000: Ch 6-7, Comin and Hobijn 2010). Subsequent productivity growth would then depend on Japan's contribution to the advancement of this common technical frontier, reducing its GDP growth potential to no more than 2\% per year (Yoshikawa 2000). The sharpness of Japan's growth decline can be further explained by a delay in the recognition of this diminished growth potential and so over-optimistic capital accumulation through the 1980s and early 1990s (Beaudry and Portier 2005, 2006, 2007). The arrival of more modest expectations then saw a loss in capital value and a decline in both investment and consumption (Ramaswamy and Rendu, 1999).

\footnotetext{
${ }^{5}$ Japan's FDI into Australia increased from 13 per cent of the total in 2008 to 25 per cent in 2009. In the same period China's share rose to 12.5 per cent. See Australian Bureau of Statistics, Balance of Payments and International Investment Position Australia, various issues.
} 


\subsection{Yielding unnecessarily to US pressure for Yen appreciation:}

That pressure from the US has been important in the setting of the yen-dollar rate since the 1980s cannot be doubted (Henning 2008, Ch 3-4). The Plaza Accord of 1985 is the most publicly famous instance but the US Exchange Rates and International Economic Policy Coordination Act of 1988 followed in response to heightened Congressional sensitivity to "exchange rate protection”. This added to pressure on Japan to appreciate its currency relative to the dollar. That this pressure extended into the 2000s is documented by Taylor (2006, 2007), who had a long interest in the Japanese economy (Taylor 1988, 1989) and held the post of Treasury Undersecretary for International Affairs in the early 2000s. In this role he sought to trade off US concern with "artificially competitive” Japanese products against the health of the Japanese economy, thereby offsetting US resistance to the nominal Yen depreciation of the early 2000s.

As indicated in Figure 4, major real appreciations relative to the US occurred on three occasions. The first was 37 per cent during 1976-78, following the first oil shock. The second was 74 per cent over 1985-88, following the Plaza Accord, due to the turning inward of financial flows following the Bank of Japan's commitment to a strong Yen. The third was 42 per cent over 1990-95, due in part to the "sudden stop" in, and therefore the relative scarcity of, Japanese output following the bursting of the property bubble and in part to the rising inefficiency of financial services during the banking crisis (Tyers 2011).

Even though two of these real appreciations were subsequently reversed, their large size would certainly have reduced the competitiveness of Japan's tradable industries, which had hitherto been the primary source of its economic growth. Indeed, they led to periods of endaka fukyo, or strong Yen induced recessions (Hamada and Okada 2009, Obstfeld 2009). But they also hurt Japanese who were investing abroad so badly as to lead to its "negative exchange rate risk premium" and hence the tolerance of very low yields at home. This position is put most cogently by McKinnon and Ohno (2001). The opposing view, put by Corbett and Ito (2010), implies that real appreciations were necessary following the convergence of Japan's wage rates with those in other OECD countries (the Balassa-Samuelson Hypothesis), and that without the corresponding nominal appreciations there would have been larger product and asset price inflations and therefore the risk of even more serious financial instability. 
These apparently conflicting positions are concordant in one respect - the non-smooth manner of the real appreciations and its implications for risk-averse behaviour on the part of Japanese savers.

\subsection{Very high productivity growth in a large near-neighbour accepting FDI:}

In economic models with two trading regions it is readily seen that accelerating productivity in one region stagnates GDP in the other as savings are drawn into the accelerating economy. Income growth (GNP rather than GDP) continues in the stagnating region, albeit more slowly than in the dynamic one. The scale of this effect in Japan's case depends on the portion of Japan's current account surplus that goes, directly or indirectly, to China (Fujiwara et al. 2008). While Ahn and Lee (2007) find supporting evidence for the case of Korea, where FDI flows to China are shown to have restrained local output growth, we have found no research that addresses the issue of conflicts between local growth and investment in China directly. Yet there is considerable indirect evidence of Japanese FDI in China, suggesting that it is extensive by comparison with all China’s trading partners (van der Eng 2011). This is not to suggest that trade and investment links with China have reduced Japanese welfare; only that the investment has contributed to Japan's stagnating GDP. Indeed, there have been considerable gains from trade with China and returns from Japanese investments must have bolstered income in Japan even if they have not contributed to its GDP. Robertson and Xu (2010), use a retrospective dynamic model to examine the zero-China-growth counterfactual. They find that other Asian economies, including Japan, benefited from Chinese growth very substantially, primarily through the effect it has had in lowering durable goods import costs. ${ }^{6}$

\subsection{Labour force contraction due to low and declining birth rate:}

There is much research to be done on the economic consequences of population decline and models that incorporate the demographic element are therefore of interest. The standard Solow-Swan growth model shows that slower population growth raises labour's marginal product and hence, for given productivity growth, the growth rate of per capita income. Were this to be observed, GDP would stagnate but GNP per

\footnotetext{
${ }^{6}$ See also the broader survey by Robertson (2010).
} 
capita would grow faster. But this view ignores the productivity consequences of an ageing labour force (Fukao et a. 2006) and consumer base and therefore the slowing of productivity growth and the weakening of markets for frontier products, which in turn weakens incentives for productivity-enhancing private investment (Fukao 2010). This could drive the productivity and labour supply issues that explain the stagnation in the analysis of Morana (2003). A related issue associated with the ageing of the labour force is relative inflexibility of older workers and therefore the more substantial matching problems that arise in labour markets through time. This alone can lead to lower labour productivity.

\subsection{The wealth shock, the debt overhang, the liquidity trap and deflation:}

The collapse of the bubble economy saw a significant wealth contraction, which rendered many firms and other institutions insolvent. The result was a short run contraction in aggregate demand. The first line of defence in such cases is monetary expansion but, such was the scale of the contraction that the power of conventional monetary policy was exhausted and the liquidity trap loomed. ${ }^{7}$ Deflation ensued and this, combined with nominal wage stickiness, sapped incentives for current domestic employment and investment. For similar reasons, the Yen could not be further depreciated to boost tradable production. Monetary expansion is, nonetheless, the best exit strategy (Ball 2008, Canova and Menz 2010) and the recent resort to “quantitative easing”, or monetary expansions through long bond acquisitions, does address this (Eggertson and Ostry 2005). But a lack of pre-commitment to monetary targets post deflation and political sensitivity to Yen depreciation effects (and US reaction in particular) appear to have been important. Moreover, the US has also been using quantitative easing since the GFC and so it has been tough to depreciate the Yen against the US\$ in any case. Moreover quantitative easing sees the central bank intervene in markets for long securities that are far more important than those for short securities in driving (external) capital account flows. Long bond acquisitions by central banks therefore reduce home long yields and redirect investment abroad. For the US this has the intended effect of placing pressure on trading partners to

\footnotetext{
${ }^{7}$ A general summary of Japan’s liquidity trap story is offered by Wilson (2000).
} 
appreciate against the dollar. For Japan, while it may have had a real depreciating effect a key consequence was surely to exacerbate the China effect.

The "balance sheet” recession (Koo 2003, 2009), where firms use new income to deleverage rather than finance further investment, relates to this since it offers a partial explanation why very low interest rates do not stimulate domestic investment. ${ }^{8}$ One difficulty with placing all explanatory eggs in this latter basket, however, is that two decades seem too long for such a force to be the dominant influence. And the idea that saved funds disappear into balance sheet restoration rather than investment raises further questions. What do creditors do with the funds thus received - why don't they recycle these into new investment? If the funds enter consumption then, from an aggregate viewpoint, they were never saved in the first place and actual saving should appear to fall while consumption rises. But there are also questions of industrial structure. Why don't investors borrow at the low interest rates and invest in greenfields projects with no debt overhang? This may be due to high cost of entry in Japan, which has experienced declining rates of business start-up (Imai and Kawagoe, 2000).

\subsection{Oligopoly and technical inefficiency in services:}

Japan has a large and comparatively inefficient services sector riven with monopolies and oligopolies and policy induced high entry and exit costs (Fukao 2010). This has been long noted (Clark 1978, Hirschmeier and Yui 1981) but solutions have been slow to appear since they tear at the Japan's cultural fabric (Kay and Clark 2005). There is even the argument that these inefficiencies are, or might potentially be, net welfare improving (Gadir 2009). Nonetheless, they cause a substantial cost burden while at the same time raising rents that take the form of corporate saving, which has remained high, the Koo thesis notwithstanding, and is the primary source of financial outflows (Japan's continuing current account surplus). The result is that growth in consumption expenditure is constrained in Japan, as elsewhere in Asia, by a high capital income share of GNP.

Following manufacturing productivity “catch-up”, further growth has been constrained by comparatively high service costs and slow consumption growth. This, and related issues, are addressed from a global perspective in multi-region modelling

\footnotetext{
${ }^{8}$ Koo’s $(2003,2009)$
} 
studies that include those by Brown et al. (1996), Wilcoxen and McKibbin (1996), Dee et al. (2000), Dee and Findlay (2009). In Japan's case, of particular concern is that the cost of business entry is comparatively high, sustaining the oligopolies and lengthening the period of adjustment to the above mentioned "balance sheet recession”. Examples of specific service policy struggles include the structure of commercial banking (McGuire 2009) and of the electric power sector (Hosoe 2006).

\section{Modelling Japanese Economic Performance: A Selective Survey}

The literature on models of Japanese performance is extensive. We begin with a brief taxonomy of modelling studies and move on to a summary of some significant ones, with the latter divided by study type.

\subsection{Economic Modelling Approaches}

There is a long standing tradition in economics to represent economic behaviour mathematically or numerically. ${ }^{9}$ The advantage of this in a social science is that it enables simulated experimentation as a substitute for scientific experiments that cannot be carried out in practice. Of relevance here are mathematical models of whole economies, which can be either constructed based on economic theory and calibrated to data for a particular year or estimated using time series econometric techniques.

\subsubsection{Theory based models}

These models are "structural" in that they formalise economic behaviour in structures consistent with widely accepted economic theory. The representation of whole economies requires, at minimum, information about consumption preferences, production technology and endowments of essential and reusable resources like labour, machinery and land. Consumption preferences can be indicated by as little as survey data showing collective expenditure on goods and services by type, though in most cases, consumption patterns can be stratified by income or socioeconomic groups. Firms and governments are incorporated as suppliers of goods and services.

\footnotetext{
${ }^{9}$ An early survey of such modeling activity is by McKibbin (1993).
} 
They use their production technologies to combine essential resources with other goods (as intermediates) to produce products and services. These elements enable the representation of markets for all goods and services and for the essential resources, labour, machinery and land. The earliest versions of these models followed the work of Johansen (1960) but the progenitors go back to Leontief (1936). ${ }^{10}$ The earliest widely used national model incorporating detailed consumption preferences and production technology was constructed in Australia by the IMPACT Project (Dixon et al. 1982). Although there are now many such models in use world-wide, specific descendants of this first exercise are the Monash model of the Australian economy (Dixon and Rimmer 2002), the USAGE model of the United States economy (Dixon and Rimmer 2004) and the GTAP model of the global economy (Hertel 1994 and Hertel ed. 1997). ${ }^{11}$

The first models were comparative static, representing whole economies in just one year and used to ask the simple question: how different would those economies have looked had some policy setting or fundamental parameter been different? Full dynamics arrived quickly, however. In the Australian context the Monash model is the most widely used example. Globally, GTAP Dynamic is another (Ianchovichina and Walmsley 2011). All these models are essentially microeconomic in that they omit the markets for money and financial assets, defining prices in terms of arbitrary numeraire goods.

At the same time as these models developed, macroeconomists were constructing dynamic models that did incorporate money and financial assets. These models tended to include only a single product and so represented consumption preferences and production technology only very cursorily. Frequently they used broad "reduced form” relationships with little theoretical foundation, depending on non-Walrasian behaviour in the Keynesian tradition. Most notable amongst such modellers was Klein (1970). Components of these models were estimated econometrically, however, using time series data, and so they were more data-dependent than the structural models. A thorough survey of applications of Klein-style models to the Japanese economy is offered by Ichimura and Klein (2010), which primarily covers modelling

\footnotetext{
${ }^{10}$ For a review, see Dixon and Rimmer (2010b).

${ }^{11}$ During the development of these models there were methodological debates over the existence, stability and uniqueness of general equilibria and over computational methods for finding them. See, for example, Scarf (1973), Shoven and Whalley (1972, 1973, 1974). These debates proved peripheral as software including Gempack and GAMS were successfully finding new general equilibria early on.
} 
in the 1950s and 1960s. The two approaches were subsequently brought together by macroeconomists seeking to incorporate more micro foundations. Amongst these were Jorgenson (1984) and McKibbin (1993). The models of Jorgenson combined detailed economic theory with time series data consistency while those of McKibbin maintained primarily calibrated structures but incorporated theoretically based representations of money and asset markets.

From the 1980s a subset of macroeconomists departed from the Keynesian tradition and built "real business cycle" models to explain economic fluctuations without resorting to strong assumptions about the rigidity of prices and wages (Lucas 1972, 1976, Sargent and Wallace 1976, Kydland and Prescott 1977). Reasons for scepticism about the role of nominal rigidities emerge from an extensive empirical literature, including for Japan Kuroda and Yamamoto (2005). The real business cycle economists were keen to improve the microeconomic foundations of their models and so developed fully dynamic general equilibrium structures. It was the age of the "efficient markets hypothesis" and so these models formed a frontier in which the represented agents were fully informed and forward-looking (had "rational expectations"). Considerable interest in this literature was shown in monetary and fiscal policy rules that public institutions could follow notwithstanding the occurrence of random or stochastic shocks. Dynamic models would be constructed incorporating these policy rules and they would be subjected to a sequence of random shocks. To examine the effectiveness of the rules, simulations would be repeated many thousands of times (Monte Carlo simulation) and the statistical distributions of key variables extracted. Such models are referred to as "dynamic stochastic general equilibrium or DSGE models”.

In the 1990s economists remaining committed to the Keynesian view that fluctuations stem from nominal rigidities developed an alternative stream of dynamic theory-based models, referred to as "new Keynesian” models. There is now a substantial literature employing such models (Obstfeld and Rogoff 1996, Rotemberg and Woodford 1997, Clarida, Gali and Gertler 1999). Recent applications to Japan include Braun and Koerber (2010). These and the real business cycle type of "DSGE" models are comparatively demanding computationally and so are thus far constrained to be small in scale and in variable numbers, which limits sectoral disaggregation and multiregion structures. This computational constraint is being gradually lifted with 
improvements in computational technique and power, however, so that another convergence is gradually taking place, between the general equilibrium models on the one hand and the new Keynesian and DSGE modelling traditions on the other.

\subsubsection{Econometric (data driven) models}

The Klein (1970) tradition of estimated dynamic macroeconomic models, despite being less well founded in theory than the dynamic general equilibrium and DSGE models, nonetheless incorporated considerable macroeconomic theory in the structures adopted. The models were large in terms of variable and equation numbers and so were rarely estimated holistically. Rather, individual equations would be separately estimated on time series data. Models of this type were implemented widely by central banks and forecasting firms, including the Bank of Japan.

At the same time, econometricians including were developing a fully non-structural simultaneous equation modelling approach called Vector Auto-Regression (VAR). ${ }^{12}$ This approach uses time lags on all variables to examine the inter-temporal links between a set of variables and the effects on all of them of shocks (or "innovations") in each one. As the method evolved opportunities to use economic theory to impose structure on the correlated errors of VAR equations arose, leading to Structural Vector Auto-Regression (SVAR).

This method is commonly used for forecasting but its application is constrained by computational and data-management constraints. Typically, less than 10 variables might be represented, thus comparing unfavourably with dynamic general equilibrium analysis from the viewpoint of incorporating behavioural theory. Mainstream dynamic general equilibrium models carry a great deal of economic behaviour by including many thousands of variables. Another weakness of the SVAR approach is that the only behaviour that is embodied is that which is represented in the sample period data on which the system is estimated. If some types of economic behaviour are dormant during the majority of the sample period they will not be represented in the estimated model. This is an important issue when economists wish to examine the impact of shocks or policy changes that have not occurred previously and a major comparative advantage for structural models.

\footnotetext{
${ }^{12}$ For the genesis of the VAR approach, see Sims (1980) and Sims et al. (1990).
} 
On the other hand, a key advantage of non-structural econometric approaches is that every variable incorporated is observed. This makes the task of testing, or “validating”, econometric models easier. Structural models frequently include many variables for which no national data source exists. Validation is carried out in both cases by simulating "out of sample” and comparing simulated values for observed variables with recorded numbers. An example of such validation testing with a dynamic general equilibrium model is Dixon and Rimmer (2010a). All models should be tested in this way if they are to be used for applied policy analysis rather than simply for "numerical theory".

\subsubsection{Hybrid models}

These are models that combine elements of Klein style macro-econometric structure with dynamic general equilibrium. They are used by central banks, treasuries and economic services firms for analysis and forecasting. They include the Oxford Economic Forecasting Model, the Bank of Japan’s JEM model and the Australian Treasury's TRIMM model.

\subsection{Modelling of the Japanese Economy}

Japan's government has a long tradition of modelling its economy, both in-house and drawing on modelling services from universities, international institutions and the private sector. Structural models have been used by the Economic Planning Agency to formulate five year plans, originally taking the simple Leontief input-output form and subsequently more complete multi-region dynamic general equilibrium structure has been used. Modelling by the Bank of Japan is reviewed in detail by Ichue et al. (2008). The "ESRI Short-Run Macro-econometric Model of the Japanese Economy” was first released in 1998. Its latest version is described in detail by Hida et al. (2008). But there are numerous modelling applications directed to Japanese policy issues that stem from academic research, such as that by Saito (2000), and work in international institutions such as the IMF. Some of these applications are briefly described here. 


\subsubsection{Structural or theory-based models}

General equilibrium studies:

These are numerous, though few examine the international effects of Japan's economic performance. An exception is the early study by Bok and McKibbin (1995), which uses a dynamic multiregional macroeconomic model (MSG3), with a single domestic product in each region, forward looking expectations and nominal wage rigidities in the new Keynesian tradition. The effects of changes in US and Japanese fiscal policies are simulated over a 1992 to 2022 forecast period. Separate simulations are offered of announced and unannounced US fiscal deficit cuts. These are compared with simulations of a rise in Japanese government spending. The results indicate that US capital outflows lower global interest rates initially, stimulating output in Australia and Korea. A permanent increase in the Japanese fiscal deficit is seen to raise aggregate Japanese demand but this is eventually crowded out by reduced domestic investment and a rise in net imports associated with are real exchange rate appreciation. In this simulation, Australia and Korea benefit from the resulting export stimulus, but a global interest rate rise decreases their investment. The simulated Japanese policy is negative for world production in the long run through reduced net global saving and therefore investment. Japanese fiscal expansion is thus beneficial to Australia in the short-to-medium term, acting through demand channels, but deleterious in the long run.

Later in the 1990s the IMF used its in-house dynamic global general equilibrium model, Multimod, to examine the influence of exchange rates on macroeconomic variables, with a focus on Japan, the US and Germany. That study found that moderate movements in US dollar exchange rates can have substantial impacts on Japanese GDP and domestic demand. The primary simulation run was a $10 \%$ appreciation shock of the US dollar. In response, Japanese GDP initially increases slightly, then decreases slightly in the medium term due to falling foreign demand. Japanese domestic demand falls continuously. US GDP falls sharply then recovers to an upward trend in the medium term. The simulations indicate moderate movements in nominal exchange rates can have measurable effects on demand and output.

During the early years of the new millennium there was considerable interest in bilateral trade agreements. These are well suited to analysis using global general 
equilibrium models with multiple products. Typical in this genre, the GTAP model has been used extensively for the purpose. The Korea-Japan relationship is examined in this way by Tomoshi and Kwan (2001), Nakajima (2002), Tomoshi (2002) and Cheong (2002). These studies find, in general, that the Korean economy is the larger proportional beneficiary from bilateral liberalisation with Japan. The Cheong approach is non-standard in that it incorporates imperfect competition, but the broad results are consistent with the earlier studies. More recently, Lee and van der Mensbrugghe (2008) examine bilateral liberalisations more widely. Their findings are as follows. First, the greater the correlation between Balassa "revealed comparative advantage” rankings of commodities with a particular FTA scenario or global trade liberalization scenario, the more likely the prospective member countries are natural trading partners and the smaller the extent of structural adjustments required postreform. Second, while agricultural liberalization causes relatively large adjustments in a number of agricultural products in some member countries (particularly in Japan and Korea), proposals under the Doha Round to exclude politically sensitive agricultural products from FTAs would significantly reduce the welfare gains for the member countries. Third, the ASEAN+3 and ASEAN+6 FTAs, with relatively large welfare gains and small structural adjustments, could be a facilitating intermediate step towards global free trade. Some of the smaller FTAs, such as the ASEAN-China and ASEAN-Korea FTAs, would result in large structural adjustments for ASEAN countries.

Other GTAP applications with relevance to Japan in the same era include that by Kagasume et al. (2002) on the global effects of tariffication of Japan's rice trade. Tiwari et al. (2002) use the same basic global model to investigate the effects of increased use of information technology and e-commerce in Japan. They find the potential for considerable efficiency gains from its use, particularly in the services sector, but they do not elaborate on the effects of this technical change abroad. Only a little later, the Brookings Institution and the IMF embarked on a study of demographic change and global financial markets. The McKibbin global models were used in this study, contributing two papers with relevance to Japan: McKibbin and Nguyen (2004) and McKibbin (2005). The first uses the MSG3 global macroeconomic model on four regions (Japan, the US, the rest of the OECD and the rest of the world). Declining fertility is found to cause big aggregate economic 
adjustments in Japan from around 2010, including falls in consumption and GDP growth relative to baseline projections but strong investment out to at least 2040 as capital is substituted for labour. Following the fertility decline, GDP is lower as expected. Households initially attempt to smooth consumption but then they cut spending in deeper swathes. The rise in investment stimulates the economy, yet there is also an increase in Japan's current account surplus, a further decline in Japanese interest rates and a nominal appreciation of the Yen by 60\%. Comparative simulations indicate that anticipation of demographic shift is important in determining the shock response.

The subsequent paper (McKibbin 2005) uses a ten-region version of the MSG3 macroeconomic model to examine the impact of both global and Japanese demographic change on the Japanese economy. Following UN demographic projections, the paper focuses on the effect population variation may have on Japanese macro-economic variables from 2005 to 2100. Simulations indicate that demographic trends will have marked impacts on Japan through financial flow variations as capital is substituted for labour locally and global demographic shifts appreciate the yen. The expansion to ten-regions allows more detailed projection of the impacts of developing and industrial country demographic change on Japan. The focus is not, however, on the implications Japan's population decline for other regions in the world. As in the earlier paper, the results indicate that the demographic transition in Japan will have important macroeconomic impacts on growth, trade flows, asset prices and investment rates. These effects include increasing global demand for capital and appreciation of the yen.

Proponents of the "real business cycle" hypothesis - that economic fluctuations stem from real shocks to supply due to changes in technology and labour market conditions (Gali 1999) - took a considerable interest in the Japanese economic stagnation of the 1990s, seeing this as a natural experiment in the implications of an underlying productivity slowdown. Beaudry and Portier (2004) offer the basic ideas, beginning with Pigou's characterisation of business cycles as commencing with excessive exuberance and hence over-investment followed by collapse as realised capital returns fall. They follow up with applications to Japan in Beaudry and Portier (2005). Emphasising errors in the anticipation of productivity changes, they are amongst the first to then include new Keynesian elements in their models, yielding from 
simulations quite close fits to the numerical record of the 1990s (Portier 2006, Beaudry and Portier 2006, 2007).

Christiano and Fujiwara (2006) follow a similar approach to Beaudry and Portier, using a dynamic general equilibrium model to explain the economic downturn of the 1990s through both demand side determinants (the Pigou cycle) and supply side determinants (an institutional shortening of working hours). They show the importance of both these sets of determinants in explaining economic fluctuations in Japan through the early to mid-1990s, using both a flex-price and a sticky price version of their model. Unfortunately, the Christiano-Fujiwara and Beaudry-Portier sdies address essentially closed economies and so no external implications are considered. In the same year Obstfeld (2006) used a generally similar dynamic general equilibrium framework, with the major difference that his study emphasised Japan's external accounts. The results suggest that, depending on assumptions about the critical substitution elasticities underlying the model, the Yen could appreciate by as much as 10 per cent for each 1 per-cent of GDP reduction in Japan's current account surplus. This study does not explore the welfare effects on Japan or the source of the necessary decline in saving that would bring about Japanese external balance. Again, neither does it directly address the implications of changes in Japanese policy and performance for other regions.

Finally, Aloy and Gente (2009) use a two-good dynamic overlapping generations model to explore the relationship between Japanese demographic change and its real exchange rate. Their model is estimated, rather than calibrated, using GMM on quarterly data between 1965 and 2001. They use numerical simulations to draw the very reasonable conclusion that Japanese labour force decline will be associated with real Yen appreciation. Implications for Japan’s trading partners are not drawn.

\section{DSGE modelling studies:}

These increasingly popular models, whether in their real business cycle or new Keynesian guise, are essentially dynamic general equilibrium models with forward looking expectations on the part of consumers and financial investors. Most constitute exercises in numerical theory and few are multi-region models. None is of the scale necessary to examine implications of economic performance in Japan for 
specific trading partners. What follows is a brief sampling of the more relevant research papers.

A key are of application of DSGE methods is the assessment of monetary policy rules. Examples of this included Fukunaga and Saito (2009), who investigate the controversy over whether central banks should target not only product but also asset price movements. Their single economy model does include nominal rigidities as well as financial market imperfections. They conclude that, where central banks have access to timely information on other than product market prices, economic performance would improve if they took asset price changes into consideration. Yet these apparent benefits decrease when central banks rely on limited information about the underlying sources of asset price movements and cannot judge which part of the observed asset price movements reflects inefficiencies in the economy. Several papers address the problem of representing liquidity traps (zero short term interest rates) in DSGE models. This largely methodological issue arises because of the difficulty of modelling with discontinuities like the zero nominal interest lower bound. We are sceptical about the merits of this research, however, since these models do not represent the whole range of maturities on debt instruments and the very low values in Japan only occur at the short end occupied by traditional monetary policy instruments. “Quantitative easing” sees the central bank managing the money supply by trading in longer maturity instruments, but to represent this requires more complicated models than those that yet fit into the DSGE framework. Yano (2009) imposes a liquidity trap exogenously by setting the single interest rate at zero in a DSGE model that is calibrated to Japanese economic structure, concluding that Japan's “lost decade” had to be explained by a slowing of underlying productivity growth.

Iwata (2009) offers an interesting application of DSGE modelling with a focus on fiscal policy and its representation. The implications of fiscal expansion depend importantly on the extent of "Ricardian equivalence", or foresight on the part of households that induces them to save for future tax burdens when the government raises spending. Full Ricardian equivalence is not observed empirically and so Iwata simulates the Japanese economy with varying shares of Ricardian households as a percentage of total households. In the model, only Ricardian households have access to financial assets, households labour supply and wages are assumed to be set via 
monopolistic competition among households, intermediate goods are produced monopolistically and final goods are produced under perfect competition. Three forms of taxation are considered, allowing comparison of fiscal multipliers. The fiscal shock simulations indicate that tax rule choice is a significant determinant of fiscal policy impact. The funding of government spending is central, not surprisingly with the most effective policies being funded by non-disincentive taxes. The results are consistent with a relatively small share of non-Ricardian households in Japan compared with the US or the Euro area.

Other significant applications of DSGE modelling address issues of model specification and the estimation of model parameters. Watanabe (2009) uses Monte Carlo simulations from two versions of a DSGE model of the Japanese economy, based originally on the model of Christiano and Fujiwara (2006), to create a large statistical sample from which behavioural equations can be estimated using vector auto-regression (VAR). This is useful to assess the formulation of macro-VARs and the extent to which they might be mis-specified. In particular, he includes habitformation in consumption and assesses its role, finding evidence in support of its inclusion in model specifications.

Sugo and Ueda (2008) construct a fully estimated DSGE model of the Japanese economy and use it to simulate a range of macro shocks to the Japanese economy, including to productivity, external demand, investment adjustment, monetary policy and inflation. Simulations indicate Japan has an average wage setting period of two quarters and an average price setting period of eight quarters. They also find Japanese monetary policy exhibits very high inertia, that the observed decline in capital utilisation rates emerges in the simulations and that a positive productivity shock decreases both inflation and hours worked. Productivity shocks appear to have a larger impact than monetary policy and an increase in hours worked results in an economic boom by reducing investment adjustment cost.

\section{Explicitly “new Keynesian” modelling studies:}

Hida et al. (2008) describe the basic structure and multipliers of the 2008 revised version of the ESRI Short-Run Macroeconometric Model of the Japanese Economy, which was first released in 1998. The model has an IS-LM-BP type (Mundell- 
Fleming) framework. It is an estimated open Keynesian model with price adjustment, in which prices are endogenised by the expectation-augmented Phillips curve. The authors find a near-unitary fiscal multiplier, larger than either the tax cut or monetary multipliers and that external shocks have relatively small impacts on domestic output. The model has 152 equations in all with 48 estimated on quarterly data with error correction dynamics. Private consumption is determined by disposable income in the short run and net assets in the long run. Results suggest a fiscal multiplier of $1 \%$, a direct tax cut multiplier of $0.2-0.6 \%$ which, for consumption tax s $-0.2 \%$. Further, a $10 \%$ yen depreciation has a $0.5 \%$ impact on GDP, $20 \%$ oil price rise $-0.1 \%$ and a $20 \%$ increase in world demand $0.1 \%$.

Many other recent studies use models on smaller scales to offer more targeted analysis. Leigh (2009) uses a stylised New Keynesian model of the Japanese economy that is estimated using Bayesian techniques that embodies habit formation to examine the comparative roles of policy and negative non-policy shocks in explaining the 'lost decade'. The results indicate that the Bank of Japan's monetary policy was not the cause of poor economic performance. Having established this, the potential impacts of alternate policy strategies to avoid deflation are evaluated, including higher inflation targets, stronger responses to output gaps and the targeting of the price-level rather than the inflation rate. The findings include that a higher inflation target (of 4\%) would have had a short-lived positive impact on output and that a stronger monetary response to the output gap would have improved output but not avoided deflation. A combination of the two policies would have prevented deflation, however, and a price-level targeting rule would have offered improved macroeconomic stability. At issue with this analysis is how the necessary monetary expansions might have been achieved, given Japan's liquidity trap, which is not addressed by Leigh. Another new Keynesian modelling exercise, by Ball (2008), also avoids the issue of overcoming the liquidity trap, by explicitly assuming "helicopter money”. His conclusions are broadly similar, however, in that stronger monetary expansions, were they possible, would have yielded better performance.

Explicit account of the liquidity trap is taken in new Keynesian modelling studies by Fujiwara et al. (2010) and Fujiwara and Ueda (2010). These are primarily exercises in numerical theory, rather than assessments of Japanese economic performance, however. The first considers the fiscal multiplier and international spill-over in an 
environment in which two countries are caught simultaneously in a liquidity trap. They show that the fiscal multiplier and spill-over effects are contrary to expectation. A fiscal expansion in one region yields a fiscal multiplier exceeding unity, a currency depreciation and a decline in the terms of trade. The fiscal spill-over to the other region is negative if the inter-temporal elasticity of substitution in consumption is less than one and positive otherwise. Incomplete stabilization of marginal costs due to the existence of the zero interest rate lower bound is shown to be a crucial factor in understanding the effects of fiscal policy in open economies. The studies also explore monetary policy spill-overs, finding the direction of these effects to depend on whether the goods produced by the two countries are complements or substitutes. Finally, once again price level targeting emerges as superior to inflation rate targeting. Braun and Koerber (2010) use a slightly different new Keynesian framework but also incorporating near zero interest rates. They also recognise that, within this framework, fiscal multipliers can be large but, when they fit the model to Japanese data, the Japanese fiscal multiplier turns out to be less than unity.

There have also been attempts to incorporate fertility decline and ageing into new Keynesian dynamic models calibrated to Japanese data. Fujiwara and Teranishi (2007) construct a dynamic new Keynesian model that incorporates life-cycle behaviour, in order to study whether structural shocks to the economy have asymmetric effects on heterogeneous agents, namely workers and retirees. They also consider whether life-cycle and demographic structure alter the dynamic properties of the monetary business cycle model, specifically the degree of amplification in impulse responses. They find that structural shocks indeed have asymmetric household effects and that demographic structure changes the magnitude of the trade-off between substitution and income effects. The modelling approach is not suited, however, to the examination of demographic change on economic performance, or to its international implications.

\subsubsection{Data-driven econometric models and studies}

There are many such studies, though again, most focus narrowly on Japanese macroeconomic policy and few examine the global implications of economic change in Japan. Fuchi et al. (2005) identify historical shocks to firms' net worth and use a 
financial accelerator model estimated as a VAR by GMM to quantify the effects of asset market shocks on wider macroeconomic variables. The data used is for 1971-99 and the GMM simulations cover 1981-2001. The results indicate that, CPI and GDP changes are strongly responsive to asset value shocks. Indeed, the results suggest that, without the asset value shocks of the early 1990s, Japan might not have experienced deflation during 90-2003.

One interesting analysis focuses on the effects of one of the most important negative shocks in the 2000s, namely that in oil import prices. Fukunaga, Hirakata and Sudo (2010) use identified VAR models to decompose oil price changes into their component parts and estimate the dynamic effects of each component on industrylevel production and prices in the U.S. and Japan. The way oil price changes affect industries depends on their characteristics as well as what kind of underlying shock drives oil price changes. Unexpected disruptions of oil supplies act mainly as negative supply shocks for oil- intensive industries and mainly as negative demand shocks for less oil-intensive industries. For most industries in the U.S., shocks to the global demand for all industrial commodities act mainly as positive demand shocks, and demand shocks that are specific to the global oil market act mainly as negative supply shocks. In Japan, oil-specific demand shocks as well as the global demand shocks act mainly as positive demand shocks for many industries.

Two data-driven econometric studies that do emphasise implications of change in Japan for its trading partners, in these cases Australia, are those by Dungey and Fry (2003) and Fry (2004). The former paper extends the Dungey and Pagan (2000) 11 variable SVAR of the Australian and rest-of-world economies by splitting the US and Japan out of the "rest-of-world". The aim is to focus on US and Japanese shocks but to identify those US shocks that are transmitted to Australia via Japan. Much behaviour is exogenous in this model, including the determination of commodity prices. By testing the statistical significance of Japanese variables in the final system, Dungey and Fry examine the degree of influence of shocks originating in Japan on Australian output. Effects on Australian variables are estimated with and without the inclusion of Japan to further assess this relationship. Not surprisingly, the results show a strong US influence over the Australian economy, albeit one that can be overspecified if the Japanese effect is not controlled for. Japanese economic variables were small in magnitude, but statistically significant in the model, establishing that 
Japan has been an important indirect transmission channel of shocks originating in the US.

Fry (2004) complements this earlier research, maintaining its focus on the significance of Japan as a channel for international shocks to Australia. The emphasis this time is on monetary policy, however. Japan is found to have a dampening impact on monetary shocks originating in the US and it is concluded that failure to consider this influence could cause Australian monetary policy to over-react.

\subsubsection{Hybrid model applications}

Since large scale hybrid models are used by almost all central banks in industrialised economies, by many treasuries and by consulting houses, there are many applications of such models and, no doubt, many that include the links between Japan and its trading partners. Most of these applications are not published in the scholarly press, however. By way of example, we restrict ourselves to two originating in Japan. Fujiwara et al. (2007) use a Bank of Japan large scale hybrid model to analyse the Bank of Japan's monetary policy in the early 1990s when the bubble economy collapsed. Stochastic simulations indicate that the monetary policy of that time was essentially optimal under uncertainty about the policy multiplier. Monetary policy was, however, not optimal under uncertainty about inflation dynamics. A more aggressive policy response than actually implemented would have improved Japan's economic performance. They find optimal monetary policy to depend significantly on the types of uncertainty the economy confronts. With the benefit of hindsight, the eventual struggle with deflation suggests more expansionary policy early in the decade. A counter-factual simulation indicates that the inflation rate and the real growth rate would have been higher to some extent if the Bank of Japan had implemented a more accommodative policy during the early 1990s. Yet the results also suggest that the effects would have been modest and that an accommodative monetary policy itself would not have changed the subsequent stagnation.

Ichiue et al. (2008) first review the range of models implemented by the Bank of Japan and used in preparing their bi-annual Outlook Report. They then focus on another large scale hybrid model, called Q-JEM, which solves for long-term general equilibria whilst capturing short-term variations through error-correction modelling. 
The model includes a collective of foreign economies and, attractively, it separates interest rates on long and short term contracts, with conventional monetary policy directly influencing only the short end. The model is demonstrated via two simulations. First, a temporary foreign slowdown decreases Japanese exports and depreciates the Yen, in turn lowering GDP growth, the domestic CPI and long-term interest rates. Second, a permanent fall in the oil import price stimulates GDP through increasing real domestic purchasing power, the CPI falls due to lower input prices, whilst long-term interest rates initially fall with the CPI before rising with GDP.

From academia, a semi-structural model in the Klein tradition is offered by Saito (2000). Usefully, Saito combines model simulations with growth accounting to explain Japan's performance in the rapid growth period, 1960-1973 and in the subsequent, slower growth period 1974-1990. In this context the model provides a consistency framework. He first uses it to decompose Japan's strong growth performance prior in 1960-1973, finding that strong technical progress in the tradable sector explains $58 \%$ of this growth while population and labour force growth explain 39\%. Other growth determinants offer negligible contributions. He then applies the same model to the slowdown in 1974-1990, the differences he sees being due to the transition to higher energy prices, flexible exchange rates, liberalisation of trade and financial capital movements and a slowdown in the rate of technical progress. He finds that the technical progress slowdown explains a third of the decline in Japan's GDP growth rate. Sadly, his analysis does not extend into Japan's “lost decade”, nor does it address specifically the implications for Japan’s trading partners.

\section{Illustrative Further Simulations}

This section summarises some research that draws on the modelling resources of the authors. The survey of modelling work in the previous section confirms the existence of a vast literature on Japanese economic performance that is of generally very high quality, even if issues of controversy, such as the precise causality of Japan's economic stagnation, are left unresolved by it. There is nonetheless an emphasis on monetary policy and very short run outlooks. Of the economic stories summarised in Section 2, the only modelling studies to explicitly address any of these issues tend to 
focus on monetary policy and the liquidity trap. Even the large real appreciations of the 1980s and 1990s are not addressed specifically using global modelling. The one longer term real story that is addressed using models is the demographic decline and this stems from early work by McKibbin (2005) and McKibbin and Nguyen (2004). Global models have not been directed to the China growth effect nor to the inefficiency of Japan's services sector. In these missing areas we offer illustrations from our own modelling, by way of suggesting areas of focus for future modelling work. In particular, we draw on applications of a global 18-region deterministic dynamic general equilibrium model, as used by Tyers and Zhang (2011) and Tyers (2011), to examine the international effects of shocks originating in Japan. ${ }^{13}$

\subsection{The model}

Industries are aggregated into seven sectors, with services little traded in comparison with the others. Failures of the law of one price are represented by product differentiation, so that consumers substitute imperfectly between products from different regions. As in other dynamic models of the global economy, the primary endogenous component of simulated economic growth is physical capital accumulation. Technical change is introduced in the form of exogenous productivity growth that is sector and factor specific, allowing the analysis of productivity performance that differs between tradable and non-tradable sectors.

Regional capital accounts are open and investors have adaptive expectations about regional net real rates of return on installed capital. In each region, the level of investment is determined by a comparison of expected net rates of return on domestic installed capital with borrowing rates by a global financial market, to which each region's saving contributes, adjusted by calibrated region-specific interest premiums. Lagged adjustment processes ensure, however, that financial capital is not fully mobile internationally in the short term, but that the paths of domestic and global interest rates eventually become parallel, separated only by exogenous premiums in the long term.

\footnotetext{
${ }^{13}$ The regions are Australia, North America (Canada, US, Mexico), Western Europe, Central Europe and the former Soviet Union, Japan, China, Indonesia, Other East and Southeast Asia, India, Other South Asia, Latin America, Sub-Saharan Africa, North Africa and the Middle East and the rest of the world.
} 
The model's characterisation of changes in labour supply and quality is augmented by a complete demographic sub-model. It tracks populations in four age groups, two genders and two skill categories: a total of 16 population groups that constitute separate households in each defined region. The skill subdivision is between production labour (unskilled) and professional labour (skilled). ${ }^{14}$ Each age-genderskill group is represented as a homogeneous sub-population with a group-specific birth and death rate, labour force participation rate, saving rate and rates of immigration and emigration. Because the non-traded sector is relatively intensive in skill, trends in skill composition prove to be particularly important. These depend on the rate at which each region's education and social development institutions transform unskilled (production-worker) families into skilled (professional-worker) families. Each year a particular proportion of the population in each productionworker age-gender group is transferred to professional status. The initial values of these proportions depend on the regions' levels of development, the associated capacities of their education systems and the relative sizes of their production and professional labour forces. Rates of transformation change through time in response to corresponding changes in real per capita income and the skilled wage premium. ${ }^{15}$

\subsection{Attribution of stagnation to observed shocks:}

Supply side determinants (productivity “catch-up exhaustion”, technical inefficiency in services and demographic changes) are most readily represented in this model, as are demand side shocks, including changes in risk premia, financial sector productivity (investment efficiency) and saving behaviour. In the now well established tradition that uses structural modelling to decompose growth performance $^{16}$, the model is used to construct a hypothetical growth path that excludes the stagnation shocks. This path is compared with the Japan’s actual performance in Figure 5. Each shock is then examined separately as a departure from this growth path and contributions to the stagnation are then apportioned. Not surprisingly,

\footnotetext{
${ }^{14}$ The subdivision between production workers and professionals and para-professionals accords with the International Labour Organisation's occupation-based classification and is consistent with the labour division adopted in the GTAP Database. See Liu et al. (1998).

${ }^{15}$ China's skill share is projected to rise through time while that in its real exchange rate comparator, North America, remains static. The contrast is due to North America’s higher initial skill share, its high rate of unskilled immigration and its higher fertility rate (Tyers and Bain 2006).

${ }^{16}$ Key general methods are described by Dixon and Rimmer (2002, 2010a). Examples related to Asian economic performance include recent work by Robertson and Xu (2010).
} 
supply side shocks, and sectoral productivity in particular, are seen to have the largest influence, though the domestic demand side stories emerge as important and not always negative in consequence. Their effect is seen to fall mainly on prices, incomes and the real exchange rate, with supply side shocks dominating changes in GDP. For the world as a whole the loss of continued Japanese growth, through the early 2000s at least, is masked by continued strong growth elsewhere in East and Southeast Asia. Simulated real global trade is smaller than it would be had Japan continued on its late-1980s path and most of Japan's trading partners are shown to have lost real exports as a consequence. Although the modelling presented does not draw a direct link between the post Plaza Accord real appreciation, the boom of the late 1980s, the bust of the early 1990s, the stagnation of real domestic investment and the subsequent productivity slowdown, this concatenation appears otherwise to have been too coincidental (Horioka 2006). Given that the US was the principal protagonist behind pressure for the late 1980s appreciation, following it up with a legislative attack on apparent exchange rate protection, it is of interest to inquire whether the US was a beneficiary from subsequent events. The analysis shows this not to have been the case. Indeed, as indicated in Figure 6, the results suggest that the global economy was retarded and real incomes in the Western industrial economies are smaller as a consequence of Japan’s stagnation. 


\subsection{Economic recovery}

To examine the shocks that might be expected to drive Japan's recovery beyond 2010, Tyers and Zhang (2011) use the model to construct elasticities of Japan's economic performance indicators to various explanatory shocks. They begin by applying small once-and-for-all shocks in Japan, measuring the dynamic consequences of each and plotting them as dynamic elasticities. They then use these to examine the effects on future economic performance of changes in Japanese productivity by industry, the Japanese saving rate and Chinese productivity.

In steady states the elasticities of real GDP to sectoral productivity are approximately value added shares. In the medium term, however, there are changes to the reallocation of global investment across regions and real exchange rate realignments that are readily captured by the model. The first set of elasticities calculated is to productivity shocks, the impacts of which on Japanese real GDP are shown in Figure 7. Service productivity proves dominant as an explanator of GDP growth, with influence that rises early on as investment is attracted into Japan and settles as the capital stock approaches a new steady state growth path.

The second indicator considered is Japan's real effective exchange rate. In the short to medium term productivity in both tradable and non-tradable industries tends to cause appreciation, as shown in Figure 8. This is because of the standard BalassaSamuelson effect on wages due to stronger tradable productivity. In the case of services, though, a rise in productivity might be expected to have the reverse effect reduced non-traded prices cause a real depreciation. This does happen in the long term, to a dominant extent. But services are intensive in skill and, in the short term, new investment is attracted into services pushing skilled wages up, raising costs by more than the productivity gain reduces them and hence appreciating the real exchange rate. The third performance indicator is real income (which includes net foreign factor income and hence is real GNP) per capita. The pattern observed is similar to that for real GDP in that services productivity has a dominant influence that is stronger in the short run due to investment effects.

Another key shock is to productivity in China's tradable industries. This affects Japan's economic performance through both financial and product markets. The dominant force in the short to medium term is the redirection of investment into China 
from the rest of the world, including Japan. This depreciates Japan's real effective exchange rate in the first decade but appreciates it later when China's increased capital stock offers lower costs. Importantly, as shown in Figure 9, real GDP is reduced over an extended period by the investment diversion and the slower growth in the Japanese capital stock.

The strongest message from these results is that "microeconomic reforms" focussing on the service sector could significantly increase its productivity. Such reforms would have the effect of reducing the cost of home capital goods and investment. More importantly, by lowering production cost in the non-traded sector, they would depreciate the real exchange rate and sustain export competitiveness.

\section{Conclusions and Priorities for Further Research}

The summary of economic stories about Japan's economic performance offered in Section 3 and that of associated modelling work in Section 4 confirm the existence of a vast literature on Japanese economic performance that is of generally very high quality, even if issues of controversy, such as the precise causality behind Japan's economic stagnation, are left unresolved by it. In this regard there have been numerous attempts to assert the dominance of domestic supply or demand side factors, though a nice summing up is by Horioka (2006) in which he indicates that both were important and, moreover, that the two were often closely interrelated. His view is that the single most important cause of the prolonged slowdown of the Japanese economy in the 1990s was the stagnation of private fixed investment, which in turn was caused by overinvestment in plant and equipment during the bubble economy of the late 1980s, the collapse of asset prices during the post-bubble period and an inadequate policy response to these events. The downturn was then exacerbated by what he feels were policy mistakes whereby macroeconomic policies in the bubble period were overly expansionary, those immediately following were overly contractionary and the attempts to resolve the problem of non-performing loans were inadequate. More specifically related to the mission of this paper, the following further points can be made about this literature:

The best work is focussed on the Japanese economy, as might be expected, though it lacks a global perspective in two respects. First, the causes of Japan's stagnation do 
stem in part from external forces, such as the bilateral protectionism of the US in the late 1980s and early 1990s that extended to the US preoccupation with exchange rates embodied in the Exchange Rates and International Economic Policy Coordination Act of 1988, the transition to inflation targeting by the major central banks in the 1990s and the associated "great moderation”, the US technology boom of the 1990s and, last but not least, the rise of China as an alternative destination for Japanese investment. All of these events affected Japan's terms of trade and its share of global investment quite independently of domestic events. Second, the size of Japan's economy ensures that the stagnation has had important implications for global economic performance and for its trading partners in particular, which are rarely touched on in the general literature and hardly at all by modelling studies.

Not only is the best work published in English focussed on domestic issues in the Japanese economy but it also gives great emphasis to macroeconomic policy, and monetary policy in particular. For writers outside Japan, the events of the past two decades have provided a test bed for real business cycle theories, new Keynesian theories and new techniques that include dynamic stochastic general equilibrium modelling. Even inside Japan most English language writing emphasises these technical issues alongside the timing of monetary easings and tightenings and the continuing liquidity trap.

What appears to suffer relative neglect, apart from the international causes and consequences of Japan's stagnation, is the microeconomic side of Japan's policy slate. After the late 1980s many governments, particularly in Europe but also in Australia and parts of Asia, embarked on programs of "microeconomic reform”. This was motivated by the new international mobility of financial capital and the perceived need for "level playing fields” to attract acceptable shares of the world's saving to home investment and to sustain home employment at politically acceptable real wage levels. More specifically, competitiveness was seen as depending not only on distortions affecting tradable industries, which had been addressed by successive rounds of negotiation under the GATT and WTO, but also by efficiency in services sectors. The result was market creation and privatisation in the electricity, telecommunications, transport and finance industries. Moreover, a key outcome of these reforms was the refocussing of redistribution policy on the tax system, with fewer distortions to labour markets. 
The Australian economy is a case in point. There, “microeconomic reforms" led to a substantial decline in comparative costs of non-traded or little traded services and a two decade depreciation of its real exchange rate. The combination of the real depreciation and the reductions in distorting policies saw the Australian economy perform strongly despite the many shocks of the period (Productivity Commission 1999). Yet there is little evidence of corresponding reforms in the Japanese economy, and surprisingly few studies of the potential gains from adopting such reforms, let alone of their potential implications for trading partners and the global economy in general.

All this said, there is a substantial English language literature on tax reform in Japan (such as Fukao 2010) in which revisions to the tax system are advocated to achieve eventual fiscal consolidation while not restraining the recovery. The emphasis is on indirect taxes, the rates of which are comparatively low in Japan, and the need for Yen depreciation notwithstanding apparent resistance by the government, the Bank of Japan and Japan's larger trading partners. Again, however, the emphasis is on macroeconomic performance rather than efficiency and long term prosperity. Because Japan's now considerable sovereign debt (twice its GDP) is denominated in Yen and it is a net saver, its economic stability would not be impaired by further real Yen depreciation. Nonetheless, should successive weak governments fail to achieve some fiscal consolidation there is the risk of a loss of confidence in government debt. A flight to real (property) and foreign-denominated assets would see the wrong kind of Yen depreciation and it would accompany sharp rises in interest rates that would further burden the government's accounts and risk default by property lenders. There is also a rising clamour in both the economics and business literatures for microeconomic reforms in the services sector and for associated further expansions in inward services FDI (Fukao 2010a, Kay and Clark 2005). The tragic events surrounding the 3-11 earthquake and tsunami have revealed the need for specific service reforms, most publicly in electricity generation and transmission. Should substantial microeconomic reforms eventually take place, the implications for Japanese and global economic performance could be profound but these remain largely uncharted, at least in the modelling literature.

From the standpoint of Japan's trading partners, these conclusions suggest the need for further research on the external causes and implications of Japan's recent 
stagnation and on the consequences for Japan's trading partners of improved service efficiency. Such issues are best addressed using models of the global economy, the scope for the further exploitation of which is considerable. Not only is there a continuing role for traditional dynamic general equilibrium models of the global economy but, to properly capture the implications of domestic microeconomic reforms will require the explicit representation of oligopoly behaviour and regulatory frameworks. The machinery to supply this research is available. Unlike the macroeconomic issues surrounding the timing of expectations about performance that underlay Japan's downturn in the 1990s, what is lacking is not constrained by the need for technical innovation in economic theory or modelling. It is more a matter of the perceived importance of the Japanese economy following the rise of China. From the standpoint of Japan's more distant trading partners, perhaps the diversion of scholarly research has been too hasty and too complete.

\section{References}

Adjemian, S. and Juillard, M. 2009. "Dealing with trends in DSGE models. An application to the Japanese economy.” ESRI Discussion Paper Series, No.224,

Ahn, S. and J. Lee, 2007. "Integration and growth in East Asia”, Bank of Japan Institute for Monetary and Economic Studies Discussion Paper 2007-E-14.

Aloy, M. and K. Gente, 2009. “The role of demography in the long run Yen-USD real exchange rate appreciation”, Journal of Macroeconomics, 31: 654-667.

Ball, L., 2008. “Helicopter drops and Japan’s liquidity trap”, Bank of Japan Institute for Monetary and Economic Studies Discussion Paper 2008-E-4.

Bayoumi, T., 2001. The morning after: explaining the slowdown in Japanese growth in the 1990s. Journal of International Economics 53 (2), 241-259.

Bayoumi, T., H. Tong and S. Wei, 2009. "The Chinese corporate savings puzzle: a firm-level cross-country perspective”, International Monetary Fund, 14 December.

Beaudry, P. and F. Portier, 2005. "Stock Prices, Total Factor Productivity and Economic Fluctuations: Evidence from Japanese Data and US Sectoral Data”, Journal of the Japanese and International Economies, 19: 635-652. , 2006. “News, Stock Prices and Economic Fluctuations”, American Economic Review,_96(4): 1293-1307, September. , 2007. "When can Changes in Expectations cause Business Cycle Fluctuations.” Journal of Economic Theory, 135(1): 458-477, July. 
Bok T.J. and W. J. McKibbin, 1995. "The Impact on the Asia-Pacific Region of Fiscal Policy in the United States and Japan”, Brooking Discussion Papers in Economics.

Boltho, A. and J. Corbett (eds), 2000. “Special Issue: Japan”, Oxford Review of Economic Policy, 16: summer.

Boltho, A. and J. Corbett, 2000. “The assessment”, in “Special Issue: Japan”, Oxford Review of Economic Policy, 16: summer.

Braun, R.A. and Y. Waki, 2006. "Monetary policy during Japan’s lost decade”, Japanese Economic Review, 57 (2): 324-344, June.

Braun, R.A. and L.M. Koerber, 2010. "New Keynesian dynamics in a low interest rate environment”, Bank of Japan Institute for Monetary and Economic Studies Discussion Paper 2010-E-5.

Brown, D., A. Deadorff, A. Fox and R. Stern, 1996. "The Liberalization of Services Trade: Potential Impacts in the Aftermath of the Uruguay Round,” in The Uruguay Round and the Developing Economies, W. Martin and L. Alan Winters (eds.), Cambridge University Press.

Canova, F. and T. Menz, 2010. “Japan’s lost decade: does money have a role?”, Journal of the Japanese and International Economies, 24: 178-195.

Cheong, I., 2002. “A Korea-Japan FTA: economic effects and policy implications”, presented at the $5^{\text {th }}$ annual Conference on Global Economic Analysis, Taipei, Taiwan.

Christiano, L. and Fujiwara, I., 2006. 'Baburu, Kajou Toushi, Jitan, Ushinawareta 10 nen' ('Bubble economy, over-investment, shorter working hours and lost decade.') Bank of Japan Institute for Monetary and Economic Studies Discussion Paper No.06-J-08.

Clarida, R., J. Gali and M. Gertler, 1999. "The science of monetary policy: a new Keynesian perspective”, Journal of Economic Literature XXXVII: 1661-1707, December.

Clark, G., 1978. "Modern nation preserves outdated attitudes: the key to Japan's economic ills is to correct the inefficiency of its tertiary industry", The Japan Times, 23 January.

Comin, D. and B. Hobijn, 2010. “Technology diffusion and post-war growth”, NBER Working Paper No. 16378, Cambridge, MA, June.

Corbett, J. and T. Ito, 2010. "What should the US and China learn from the past USJapan conflict?” VOX: Research-Based Policy Analysis and Commentary, www.voxeu.org, 24 November.

Dee, P., A. Hardin and L. Holmes, 2000. "Issues in the application of CGE models to services trade liberalisation”, in C. Findlay and T. Warren (eds), Impediments to Trade in Services: Measurement and Policy Implications, Routledge, London, pp. 267-86.

Dee, P. and C. Findlay, 2009. "Services in PTAs donuts or holes?” in S. Jayasuriya, D. MacLaren and G. Magee (eds), Negotiating a Preferential Trading Agreement: Issues, Constraints and Practical Options, Edward Elgar, Cheltenham UK, pp. 97-128. 
Dixon, P.B., B.R. Parmenter, John Sutton and D.P. Vincent, 1982. ORANI: A Multisectoral Model of the Australian Economy, Contributions to Economic Analysis 142, North-Holland Publishing Company, pp. xviii + 372.

Dixon, P.B. and M.T. Rimmer, 2002. Dynamic General Equilibrium Modelling for Forecasting and Policy: a Practical Guide and Documentation of MONASH, Contributions to Economic Analysis 256, North-Holland Publishing Company, pp. xiv+338.

, 2004. "The US economy from 1992 to 1998: results from a detailed CGE model”, Economic Record, Vol. 80(Special Issue), September, pp.S13-S23.

, 2010a. "Validating a detailed, dynamic CGE model of the U.S.”, Economic Record, forthcoming.

, 2010b. “Johansen’s contribution to CGE modelling: originator and guiding light for 50 years”, Monash University Centre of Policy Studies General Paper No. G203, May.

Dungey, M. and R. Fry, 2003. "International shocks on Australia - the Japan effect”, Australian Economic Papers, June: 159-182.

Dungey, M. and A. Paganrian, 2000. "A structural VAR model of the Australian economy," The Economic Record, The Economic Society of Australia, 76(235): 321-42, December.

Economist, The, 2010. “Into the unknown: a special report on Japan”, November 2026 Issue, 22pp.

Eggertson G. and Ostry J., 2005. “Does excess liquidity pose a threat to Japan?”, IMF Policy Discussion Paper PDP/05/5.

Fry, R., 2004. 'International demand and liquidity shocks in a SVAR model of the Australian economy', Applied Economics, 36: 849-863.

Fuchi, H., Muto, I. and Ugai, H., 'A Historical Evaluation of Financial Accelerator Effects in Japan's Economy.' Bank of Japan Institute for Monetary and Economic Studies Discussion Paper No.05-E-8, 2005.

Fujiwara, I., N. Hara, N. Hirakata, T. Kimura and S. Watanabe, 2007. “Japanese monetary policy during the collapse of the bubble economy: a view of policymaking under uncertainty”, Bank of Japan Institute for Monetary and Economic Studies Discussion Paper 2007-E-9.

Fujiwara, I., T. Nakajima, N. Sudo and Y. Teranishi, 2010. “Global liquidity trap”, Bank of Japan Institute for Monetary and Economic Studies Discussion Paper 2010-E-11, July.

Fujiwara, I., K. Otsu and M. Saito, 2008. “The global impact of Chinese growth”, Bank of Japan Institute for Monetary and Economic Studies Discussion Paper No. 08-E-22, September.

Fujiwara, I., N. Sudo and Y. Teranishi, 2009. "Global liquidity trap: a simple analytical investigation”, Bank of Japan Institute for Monetary and Economic Studies Discussion Paper 2010-E-31.

Fujiwara, I. and Y. Teranishi, 2007. "A dynamic new Keynesian life-cycle model: societal ageing, demographics and monetary policy”, Bank of Japan Institute for Monetary and Economic Studies Discussion Paper 2007-E-4. 
Fujiwara, I. and K. Ueda, 2010. "The fiscal multiplier and spill-over in a global liquidity trap”, Bank of Japan Institute for Monetary and Economic Studies Discussion Paper 2010-E-3.

Fukao, K., 2010, "Service sector productivity in Japan: the key to future economic growth”, Research Institute of Economy, Trade and Industry, IAA, Discussion Paper 10-P-007, August.

Fukao, K., R. Kambayashi, D. Kawaguchi, H.U. Kwon, Y.G. Kim and I. Yokoyama, 2006. "Deferred compensation: evidence from employer-employee matched data from Japan”, Hi-Stat Discussion Paper No.187, Hitotsubashi University, October.

Fukao, M., 2010. "Financial crisis and long term stagnation in Japan: fiscal consolidation under deflationary pressures”, Keio-Kyoto Global Center of Excellence Discussion Paper DP2010-010.

Fukunaga, I., N. Hirakata and N. Sudo, 2010. "The effects of oil price changes on industry level production and prices in the US and Japan”, Bank of Japan Institute for Monetary and Economic Studies Discussion Paper 2009-E-24, October.

Gadir, Jonathan, 2009. “The value of Japanese inefficiency”, NewMatilda.com.

Goyal, R. and R,I. McKinnon, 2003. “Japan’s negative risk premium in interest rates: the liquidity trap and the fall in bank lending”, The World Economy 26: 339363, March.

Hamada, K. and Y. Okada, 2009. "Monetary and international factors behind Japan's lost decade”, Journal of the Japanese and International Economies, 23: 200219.

Hamao, Y., J. Mei and Y. Xu, 2007. "Unique symptoms of Japanese stagnation: an equity market perspective”, Journal of Money Credit and Banking, 39(4): 901-923.

Hayashi, F. and E.C. Prescott, 2002. “The 1990s in Japan: a lost decade”, Review of Economic Dynamics, 5: 206-235.

Henning, C.R., 2008. Accountability and Oversight of US Exchange Rate Policy, Washington DC: Peterson Institute for International Economics, June.

Hertel, T., 1994. “Taking IMPACT Abroad: the Global Trade Analysis Project”, paper presented at the IFAC Meetings on Computational Methods in Economics and Finance, Amsterdam, June 8, pp. 26, available as technical document PPAP0077 on http://www.monash.edu.au/policy/archivep.htm.

Hertel, T.W. (ed.), 1997. Global Trade Analysis Using the GTAP Model, Cambridge University Press, New York.

Hosoe, N., 2006. “The deregulation of Japan's electricity industry”, Japan and the World Economy 18: 230-246.

Hida, F., Tanaka, K., Umei, H., Iwamoto, K. and Shigihara, H., 2008. 'Tanki Nippon Keizai Makuro Keiryou Moderu (2008 Nen Ban) no Kouzou to Jousu Bunseki' ('The ESRI Short-Run Macroeconometric Model of the Japanese 
Economy: Basic Structure, Multipliers, and Economic Policy Analyses’) ESRI Discussion Paper Series, No.201, 2008.

Hirschmeier, J. and T. Yui, 1981. The Development of Japanese Business, London: George Allen and Unwin.

Horioka, C.Y., 2006. “The causes of Japan's 'lost decade': the role of household consumption”, Japan and the World Economy 18: 378-400.

Hoshi, T. and A.K. Kashyap, 2004. "Japan’s financial crisis and economic stagnation”, Journal of Economic Perspectives, 18(1): 3-26.

Ianchovichina, E. and R. McDougall, 2000. “Theoretical structure of Dynamic GTAP”, GTAP Technical Paper No.17, Purdue University, December (http://www.agecon.purdue.edu/gtap/GTAP-Dyn).

Ianchovichina, E. and T. Walmsley, 2010. Dynamic Modeling and Applications in Global Economic Analysis, Cambridge University Press.

Ichimura, S., 2010. “A historic survey of macro-econometric models in Japan”, Chapter 1 in S. Ichimura and L. R. Klein (eds), Macroeconometric Modeling of Japan, World Scientific Press.

Ichiue, H., Kojima, S. Shirota, T., Nakamura a, K. and Hara, N., 2008. 'Chuou Ginkou niokeru Makuro Keizai Moderu no Riyou Joukyou' ('Macroeconomic models used by Central banks.') Bank of Japan Review, 2008-J-13, 2008. (in Japanese).

Ichiue, H., Kojima, S. Shirota, T., Nakamura, K., Hara, N., 2008, 'Macroeconomic models used by Central Banks’, Bank of Japan Review, December (2008-J13).

International Monetary Fund, World Economic Outlook, May 1998

Imai, Y. and M. Kawagoe, 2000. "Business start-ups in Japan: problems and policies”, Oxford Review of Economic Policy, 16: summer: 114-123.

Iwata, Y., 'Fiscal Policy in an Estimated DSGE Model of the Japanese Economy: Do Non-Ricardian Households Explain All?’ ESRI Discussion Paper Series, No.216, 2009.

Johansen, L., 1960. A Multisectoral Study of Economic Growth, Contributions to Economic Analysis 21, North-Holland Publishing Company, pp. x+177.

Jorgenson, D.W., 1984. "Econometric methods for applied general equilibrium analysis" pp. 139-203 in H.E. Scarf and J.B. Shoven (editors), Applied General Equilibrium Analysis, Cambridge University Press, New York.

Jorgenson, D.W. and K. Nomura, 2007. “The industry origins of the US-Japan productivity gap”, Economic Systems Research, 19: 315-341.

Kagatsume, M., C. Chang and C. Wu, 2002. "A general equilibrium analysis of Japan's rice tariffication”, presented at the $5^{\text {th }}$ annual Conference on Global Economic Analysis, Taipei, Taiwan.

Kay, C. and T. Clark, 2005. Saying Yes to Japan: How Outsiders are Reviving a Trillion Dollar Services Market, New York: Vertical Inc, May. 
Klein, L.R., 1970. An Essay on the Theory of Economic Prediction, Markham Economics Series, Chicago: Markham Publishing Company.

Koo, R.C., 2003. Balance Sheet Recession: Japan's Struggle with Uncharted Economics and its Global Implications, Clementi Loop, Singapore: John Wiley and Sons. , 2009. The Holy Grail of Macroeconomics: Lessons from Japan's Great Recession, revised edition, John Wiley and Sons, August.

Krugman, P.R., 1998. “It's baaack: Japan's slump and the return of the liquidity trap”, Brookings Papers on Economic Activity, 2: 237-205.

Kuroda, S. and I. Yamamoto, 2005. "Wage fluctuations in Japan after the bubbleburst economy: downward nominal wage rigidity, payrolls and the unemployment rate”, Bank of Japan Institute for Monetary and Economic Studies Discussion Paper 2005-E-2.

Kydland, F.E. and E.C. Prescott, 1977. "Rules versus discretion: the inconsistency of optimal plans”, Journal of Political Economy, 85: 473-492.

Lee, H. and D. van der Mensbrugghe, 2008. “Alternative regional integration scenarios in East Asia and structural adjustments in member countries”, presented at the annual Conference on Global Economic Analysis, Helsinki, Finland.

Leigh, D., 2009. 'Monetary Policy and the Lost Decade: Lessons from Japan.' IMF Working Paper, WP/09/232.

Leontief, W.W. (1936), “Quantitative Input-Output Relations in the Economic System of the United States”, The Review of Economics and Statistics, 18(3): 105-125, August.

Lincoln, E.J., 1988. Japan: Facing Economic Maturity, Washington DC: The Brookings Institution.

Lucas, R.E., 1972. "Expectations and the neutrality of money", Journal of Economic Theory, 4: 103-124.

, 1976. "Econometric policy evaluation: a critique”, Carnegie-Rochester Conference Series on Public Policy, 1: 19-46.

McGuire, P., 2009. "Bank ties and firm performance in Japan: some evidence since FY2002”, Bank of Japan Institute for Monetary and Economic Studies Discussion Paper 2009-E-3.

McKibbin W. and Nguyen L., 2004. "Modelling global demographic change: results for Japan”, Brookings Discussion Papers in International Economics, No.165, April.

McKibbin, W. J., 1993. "Integrating macro-econometric and multi-sector computable general equilibrium models”, Brookings Discussion Papers in International Economics, No 100. , 2005. "Global demographic change and Japanese macroeconomic performance”, Brookings Discussion Papers in International Economics No.169, June. 
McKinnon, R. and K. Ohno, 2001. "The foreign exchange origins of Japan's economic slump and low interest liquidity trap”, The World Economy 24: 279315, March.

Miyao, R., 2006. "Nihon keizai no hendou youin: seisansei shokku no yakuwari (Causes of fluctuations in the Japanese economy: the role of productivity shocks)”, Bank of Japan Working Paper Series No. 06-J-1, January (in Japanese).

Morana, C. 2004. “The Japanese stagnation: an assessment of the productivity slowdown hypothesis”, Japan and the World Economy. , 2007. "The end of the Japanese stagnation: an assessment of the policy solutions”, International Centre for Economic Research, Torino, Working Papers No. 27/2006, August.

Motonishi, T. and H. Yoshikawa, 1999. "Causes of the long stagnation of Japan during the 1990s: financial or real?”, Journal of the Japanese and International Economies, 13: 181-200.

Nadenichek, J., 2007. “Consumer confidence and economic stagnation in Japan”, Japan and the World Economy, 19: 338-346.

Nakajima, T., 2002. “An analysis of a Japan-Korea FTA: sectoral aspects”, presented at the 5th Annual Conference on Global Economic Analysis, Taipei, Taiwan.

Nakatani, T. and P. Skott, 2006. "Japanese growth and stagnation: a Keynesian perspective”, Working Paper 2006-4, Department of Economics, University of Massachusetts at Amherst.

Obstfeld, M., 2008. “Time of troubles: the Yen and Japan’s economy, 1985-2008”, presented at the ESRI-Chincago GSB-Columbia Business School Conference on “Japan's Bubble, Deflation and Long Term Stagnation”, Federal Reserve Bank of San Francisco, December 11-12.

Obstfeld, M. and K. Rogoff, 1996. Foundations of International Macroeconomics, Cambridge MA: The MIT Press.

Paprzycki, R. and K. Fukao, 2004. "Overcoming economic stagnation in Japan: the importance of total factor productivity and the potential contribution of foreign direct investment”, Hitotsubashi University Research Unit for Statistical Analysis in Social Sciences, Institute of Economic Research Discussion Paper No.39, August.

Peri, G., 2010. "The effect of immigration on productivity: evidence from the United States”, NBER Working Paper 15507, Cambridge Massachusetts.

Portier, F., 2006. “A ‘news’ view of Japan’s lost decade: monetary policy”, Japanese Economic Review 57 (2): 345-357, June.

Productivity Commission, Government of Australia, 1999. Microeconomic Reforms and Australian Productivity: Exploring the Links, Commission Research Paper in 2 volumes, Canberra, November.

Ramaswami, R. and C. Rendu, 1999. “Japan’s stagnant nineties - a vector autoregression perspective”, IMF Working Paper WP-99-45. 
Robertson, P.E., 2011. "Deep impact: China and the world economy”, presented at the $45^{\text {th }}$ Foreign Policy School, University of Otago, June, forthcoming Working Papers in Economics, UWA Business School, Perth.

Robertson, P.E. and J.Y. Xu, 2010. "In China's wake: has Asia gained from China's growth?” Economics Discussion paper 10.15, UWA Business School, Perth, June.

Rotemberg, J. and M. Woodford, 1997. “A optimization-based econometric framework for the evaluation of monetary policy”, NBER Macroeconomics Annual 12: 297-346.

Saito, M., 2000. The Japanese Economy, World Scientific, Vol.1 in the "Economic Ideas Leading to the $21^{\text {st }}$ Century" series edited by L.R. Klein and V. Su.

Sargent, T. and N. Wallace, 1976. "Rational expectations and the theory of economic policy”, Journal of Monetary Economics, 2: 169-183.

Scarf, H.E., 1973. The computation of economic equilibria, New Haven and London:Yale University Press, pp. $\mathrm{x}+249$.

Selahattin, I. and N. Sudo, 2010. "Productivity and fiscal policy in Japan: short term forecasts from the standard growth model”, Bank of Japan Institute for Monetary and Economic Studies Discussion Paper No. 2010-E-23, September.

Shoven, J.B. and J. Whalley, 1972. "A general equilibrium calculation of the effects of differential taxation of income from capital in the U.S.”, Journal of Public Economics, 1: 281-321.

, 1973. "General equilibrium with taxes: A computational procedure and an existence proof”, Review of Economic Studies, 40: 475-489.

, 1974. "On the computation of competitive equilibrium in international markets with tariffs”, Journal of International Economics, 4: 341-354.

Sims, CA 1980, 'Macroeconomics and Reality', Econometrica, 48(1) 1-48.

Sims, CA, Stock, JH \& Watson, MW 1990, 'Inference in Linear Time Series Models with some Unit Roots’, Econometrica, 58(1) 113-144.

Sugo, T. and Ueda, K., 2008. "Estimating a dynamic stochastic general equilibrium model for Japan”, Journal of the Japanese and International Economies, 22(4):476-502.

Taylor, J.B., 1988. “Japanese macroeconomic policy and the current account under alternative international monetary regimes”, Bank of Japan Monetary and Economic Studies, 6(1): 1-36.

,1989. "Differences in economic fluctuations in Japan and the United States: the role of nominal rigidities", Journal of the Japanese and International Economies, 3: 127-144.

, 2006. 'Lessons from the recovery from the 'lost decade' in Japan: the case of the great intervention and monetary injection”, Background Paper for the International Conference of the Economics and Social Research Institute, Cabinet Office, Government of Japan, September. , 2007. Global Financial Warriors: the Untold Story of International Finance in the Post 9/11 World, New York: W.W. Norton. 
Tiwari, P., M. Doi and H. Itoh, 2002. “A role for information technology in the Japanese economy: a CGE analysis”, Presented at the 5th Annual Conference on Global Economic Analysis, Taipei, Taiwan.

Tyers, R., 2011. “Global implications of Japanese economic stagnation”, presented at the Australian Conference of Economists, Australian National University, July 2011, CAMA Working Paper 20-2011, June, Australian National University.

Tyers, R. and I. Bain, 2006. "The global economic implications of freer skilled migration”, Working Papers in Economics and Econometrics No 468, Australian National University, Canberra, revised September 2007.

Tyers, R. and F. Lu, 2008. “Competition policy, corporate saving and China’s current account surplus”, Working Papers in Economics and Econometrics No. 496, College of Business and Economics, Australian National University, July.

Tyers, R. and L. Rees, 2008. “Service Oligopolies and Australia’s Economy-Wide Performance”, Working Papers in Economics and Econometrics No.490 (ISBN 086831490 0), and Centre for Applied Macroeconomic Analysis Working Paper 5/2008, College of Business and Economics, Australian National University, Canberra, March.

Tyers, R. and Y. Zhang, 2011. “Japan’s economic recovery: insights from real multiregion dynamics”, paper presented at the conference on Australia, Japan and the Region 30 Years On, in the 30th Anniversary Year of the ANU's Australia-Japan Research Centre, CAMA Working Paper 18-2011, Australian National University, Canberra 28-29 March.

Van Ark, B., 2005. "Has the Japanese economy turned the corner: an international comparative perspective on Japan's productivity revival”, The Japanese Economy, 33(3): 10-26, Fall.

van der Eng, P., 2011. "Expatriation strategies of Japanese MNEs in Asia”, presented at "Australia, Japan and the Region 30 years on: a conference in the $30^{\text {th }}$ anniversary year of the Australia Japan Research Centre”, Australian National University 28-29 March.

Vines, D., 2010. “Global fiscal consolidation, the G20’s mutual assessment process and reform of the international monetary system”, presented at the Macroeconomy Research Conference on Fiscal Policy in the Post Crisis World, Tokyo, 16 November 2010.

Watanabe,T., 2009. 'The Application of DSGE-VAR Model to Macroeconomic Data in Japan.’ ESRI Discussion Paper Series, No.225-E.

Wilcoxen, P. and W.J. McKibbin, 1996. "Services in modelling the global economy”, Asia Pacific Economic Review, 2(2).

Wilson, D., “Japan's slow-down: monetary versus real explanations”, Oxford Review of Economic Policy, 16: summer: 18-33.

Yano, K., 'Dynamic Stochastic General Equilibrium Models Under a Liquidity Trap and Self-organizing State Space Modeling.’ ESRI Discussion Paper Series, No.206, 2009.

Yoshikawa, H., 2000. "Technical progress and the growth of the Japanese economy, past and future”, Oxford Review of Economic Policy, 16: summer: 34-45. 
Figure 1: Japan's Nominal and Real GDP ${ }^{\mathrm{a}}$

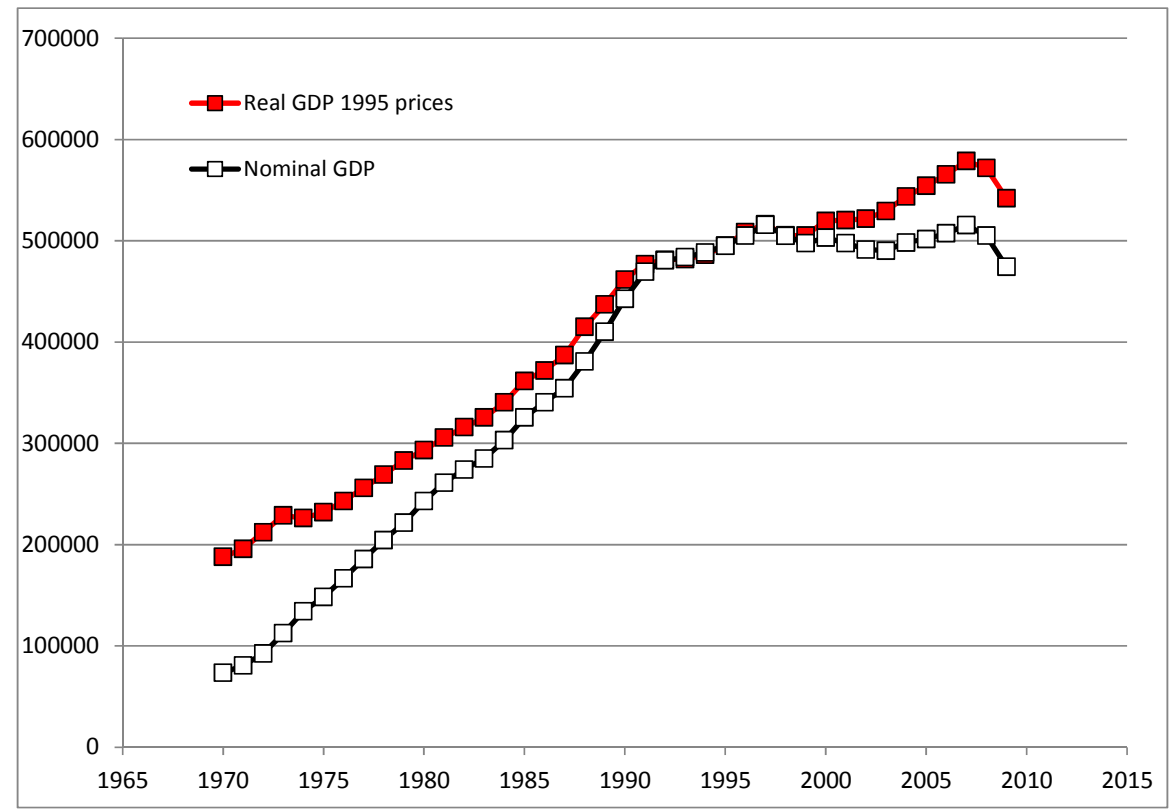

a Here Japan's nominal GDP in Yen is deflated by its GDP deflator with 1995=1.0. Source: IMF, International Financial Statistics.

Figure 2: Economic Performance Measures After 1990

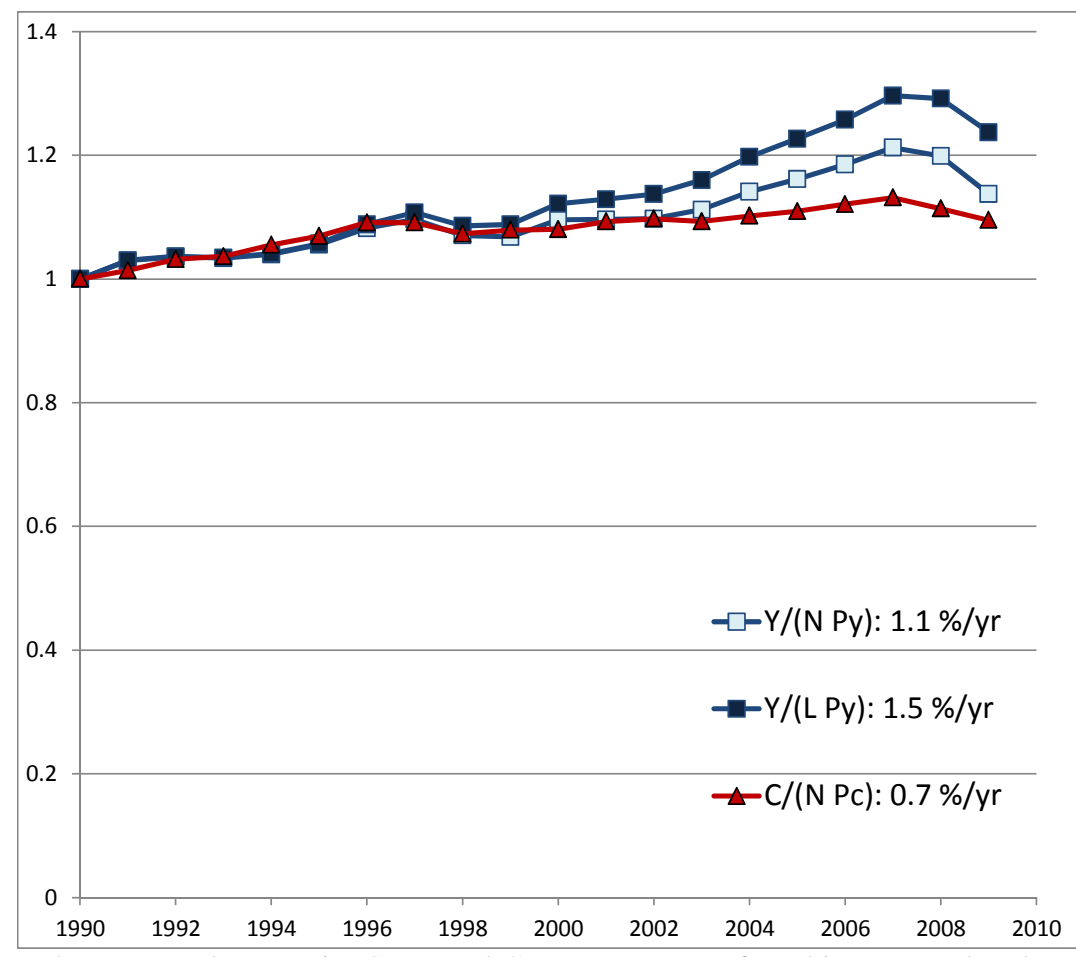

a These are real per capita GDP, real GDP per person of working age and real consumption expenditure per capita (deflated using the CPI). Growth rates are 1990-2007. $N$ is population, $L$ is the number of working age (15-65), $P_{Y}$ is the GDP deflator and $P_{C}$ is the consumer price index.

Sources: IMF, International Financial Statistics. 
Figure 3: Shares of Global GDP after $1990^{\mathrm{a}}$

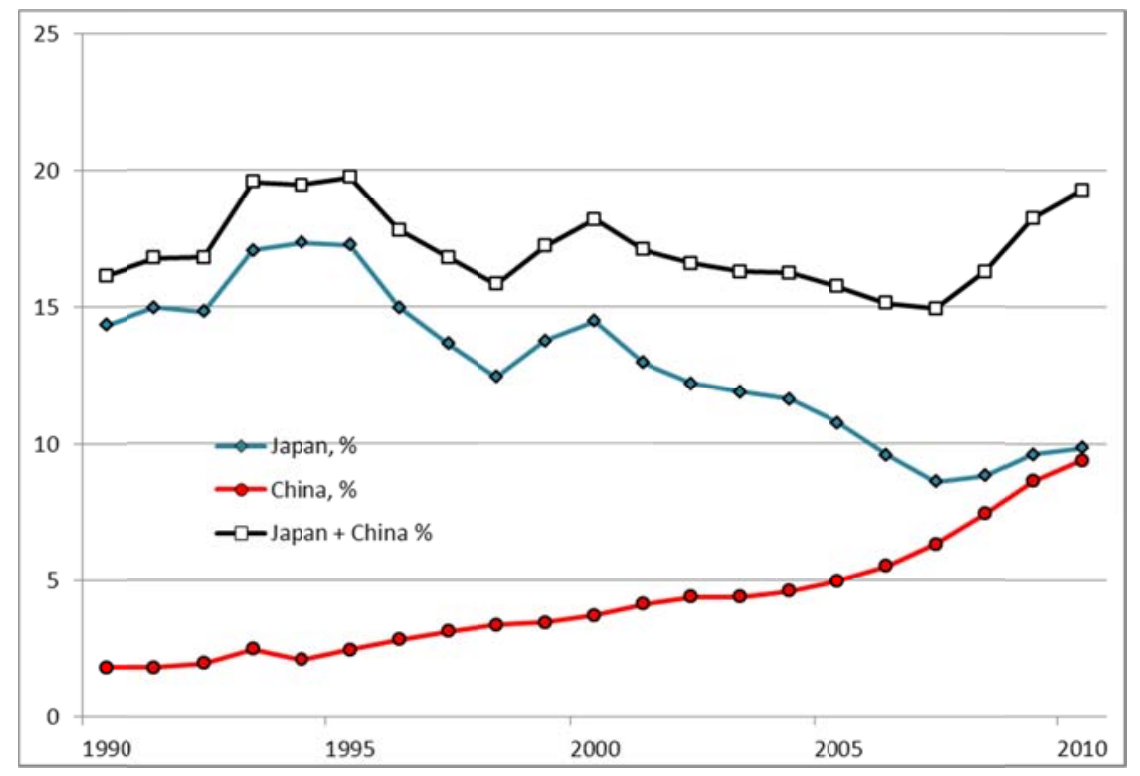

a Although PPP adjusted data are available from this source that shift the China share substantially, this figure uses market exchange rate weights since the difference concerns primarily non-traded service prices which are irrelevant to the commercial scale of China as perceived from abroad.

Source: Penn World Tables.

\section{Figure 4: Japan's Real Exchange Rate Against the United States ${ }^{a}$}

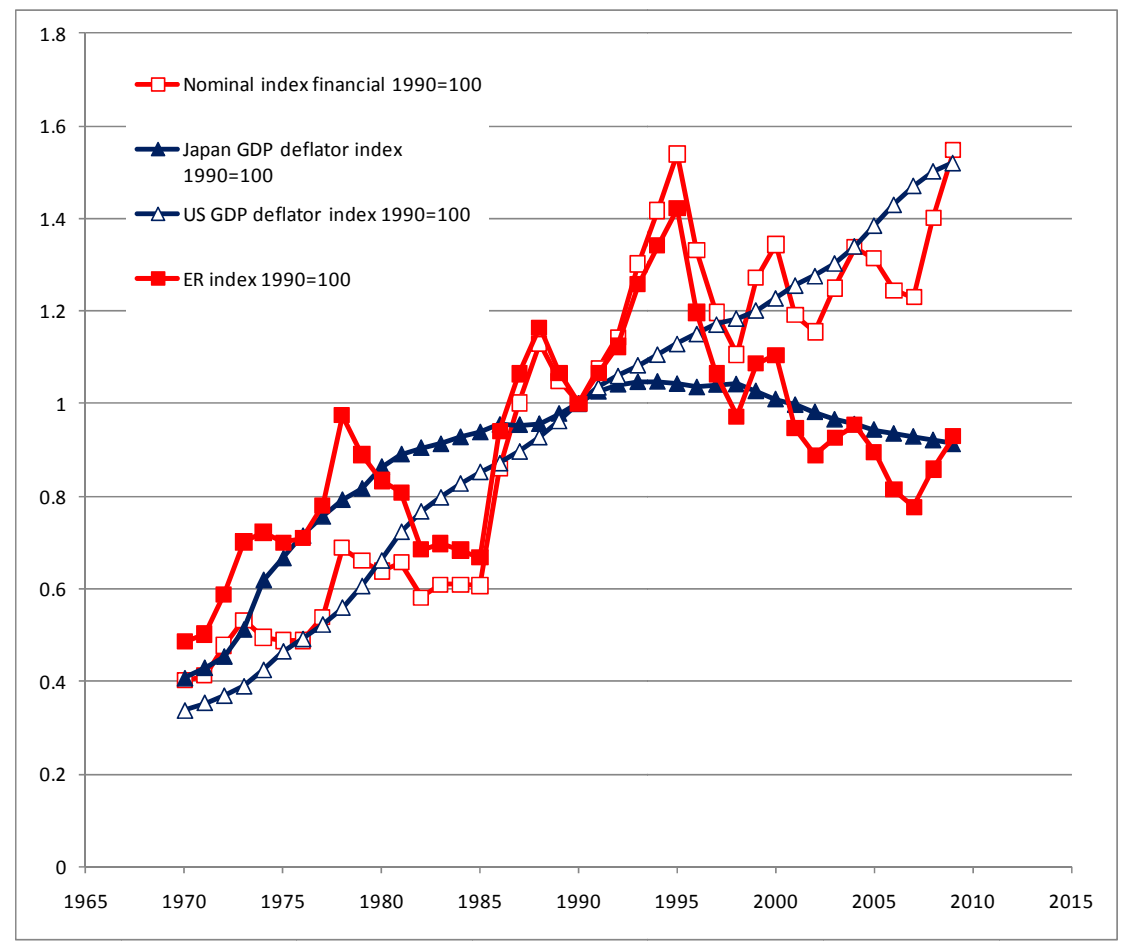

a Here the exchange rates are defined financially, so that appreciations are increases, and the real exchange rate is the nominal times the home GDP price divided by the foreign GDP price.

Source: IMF, International Financial Statistics, various issues. 
Figure 5: Japan 1985-2010 Actual and Simulated Economic Performance (Indices 1985=1.0)

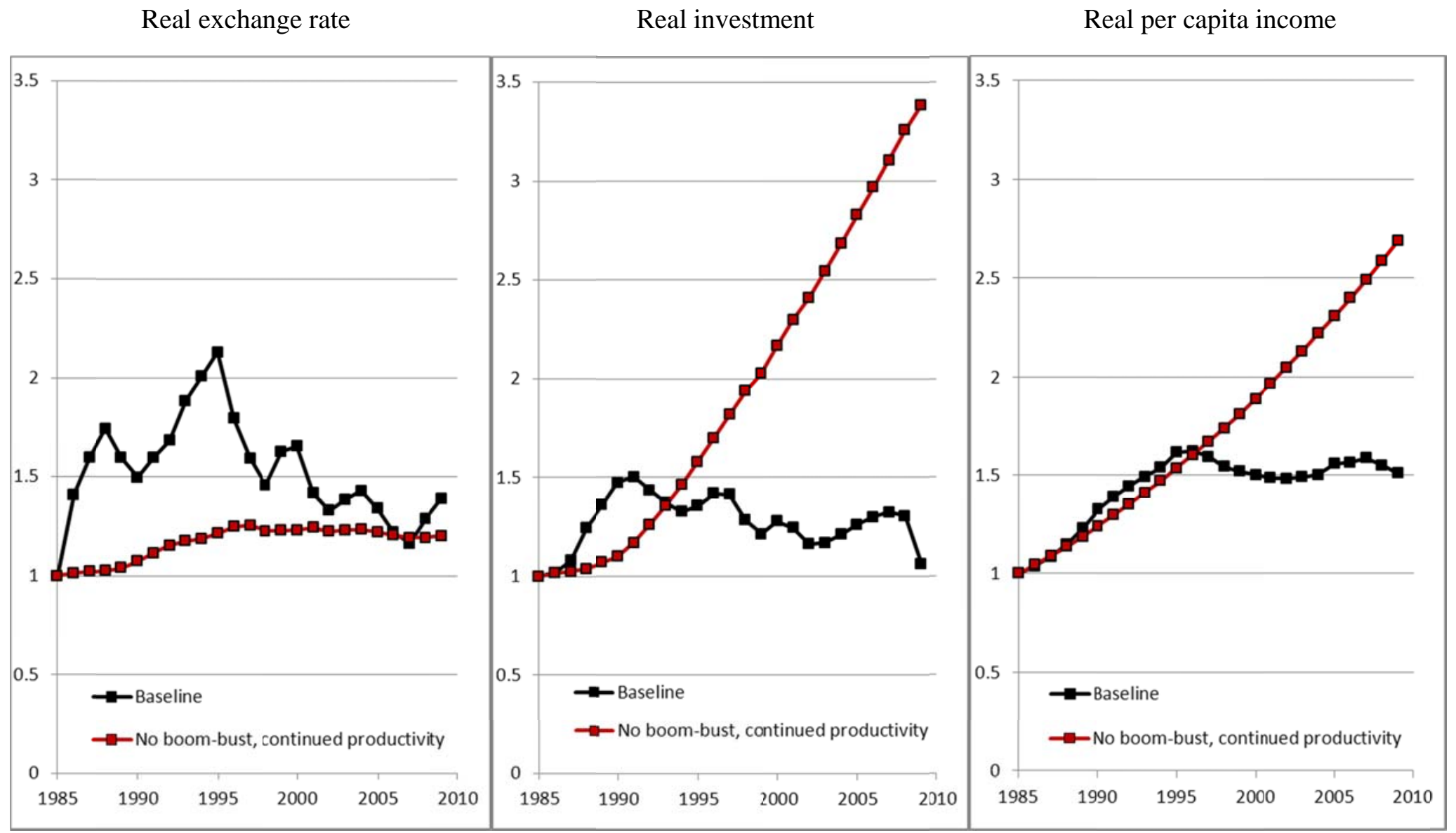

Source: Tyers (2011) 


\section{Figure 6: Real per Capita Income Difference, Baseline Relative to the No Boom-Bust Scenario ${ }^{\text {a }}$}

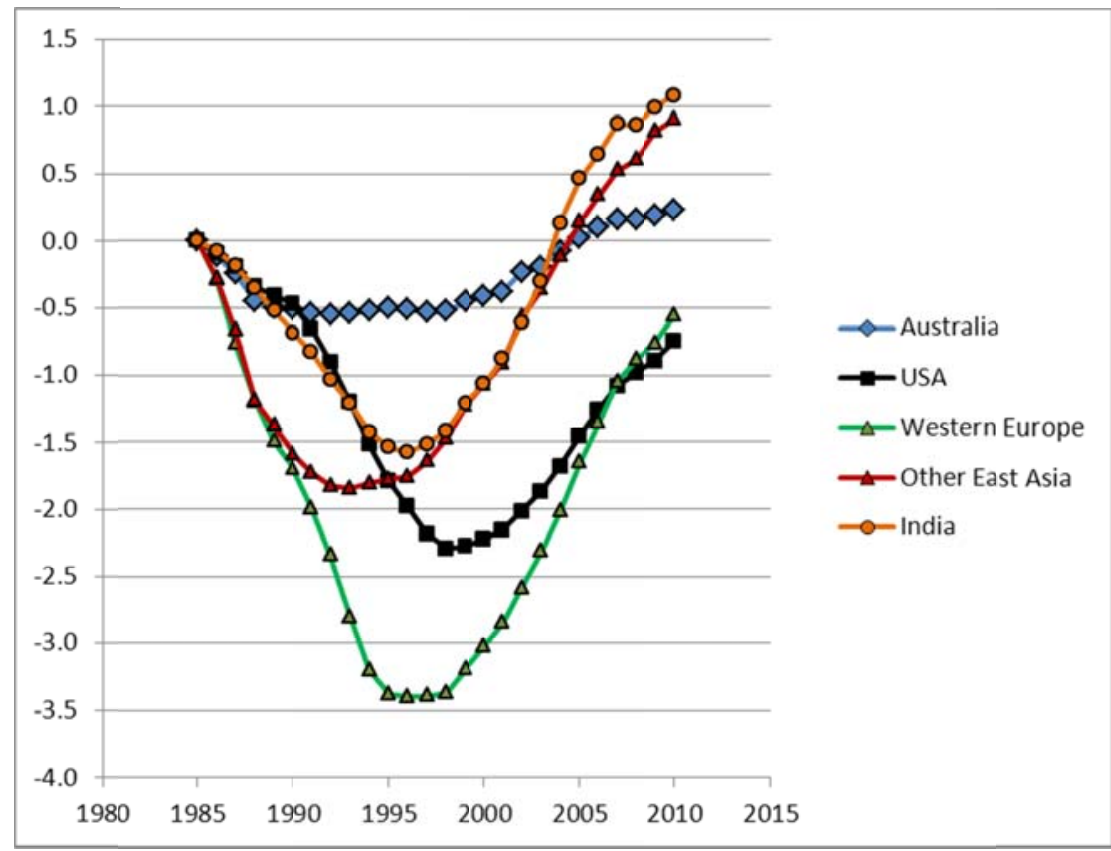

a Cumulative per cent changes, from simulations of the model described in the text. Source: Tyers (2011).

\section{Figure 7: Elasticities of Japan's Real GDP to Productivity Shocks ${ }^{\mathrm{a}}$}

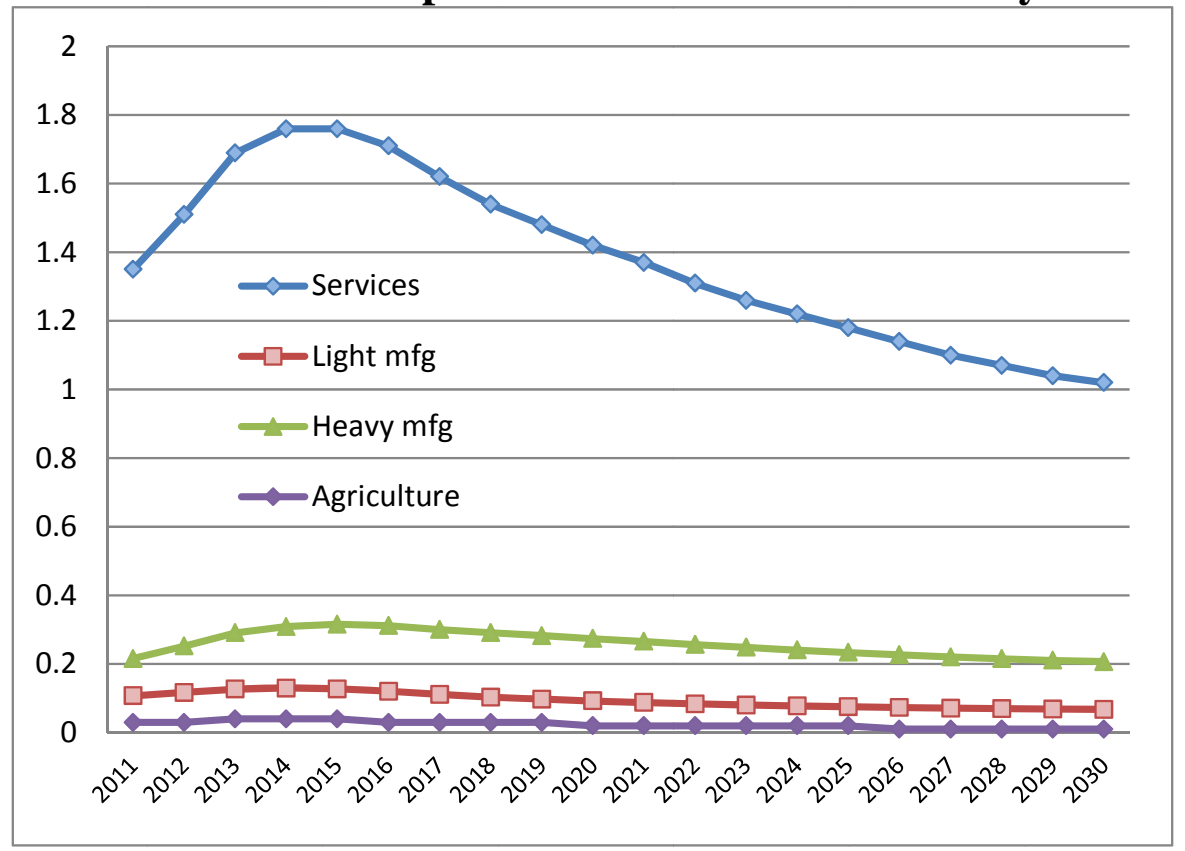

a Here a once and for all one per cent rise in the level of sectoral total factor productivity is imposed in 2011. The graph shows the subsequent path of real GDP in cumulative per cent deviations from a baseline simulation. These deviations are then elasticities of response.

Source: Simulations of the model described in the text.

Source: Tyers and Zhang (2011). 
Figure 8: Elasticities of Japan's Real Effective Exchange Rate to Productivity Shocks ${ }^{\mathrm{a}}$

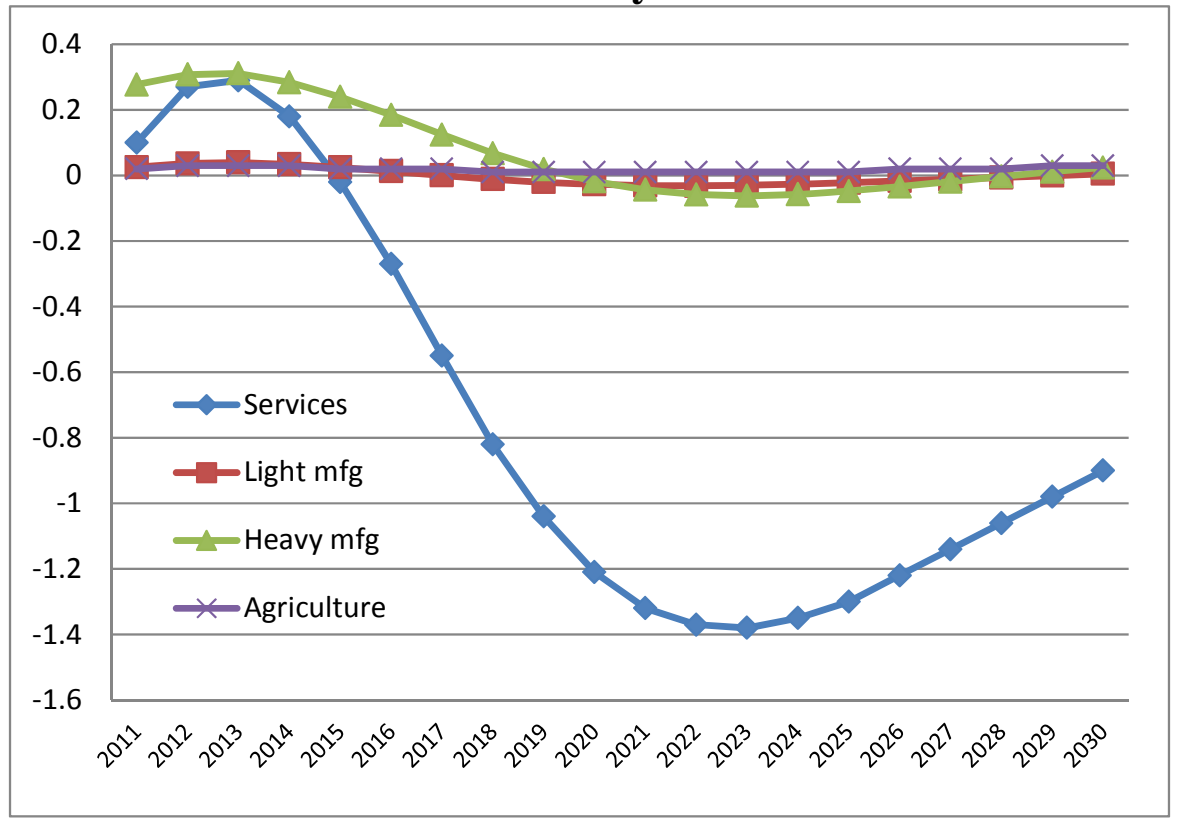

a Here a once and for all one per cent rise in the level of sectoral total factor productivity is imposed in 2011. The graph shows the subsequent path of the real effective exchange rate in cumulative per cent deviations from a baseline simulation. These deviations are then elasticities of response.

Source: Tyers and Zhang (2011).

\section{Figure 9: Elasticities of Japanese Economic Performance} to a Chinese Productivity Shock ${ }^{a}$

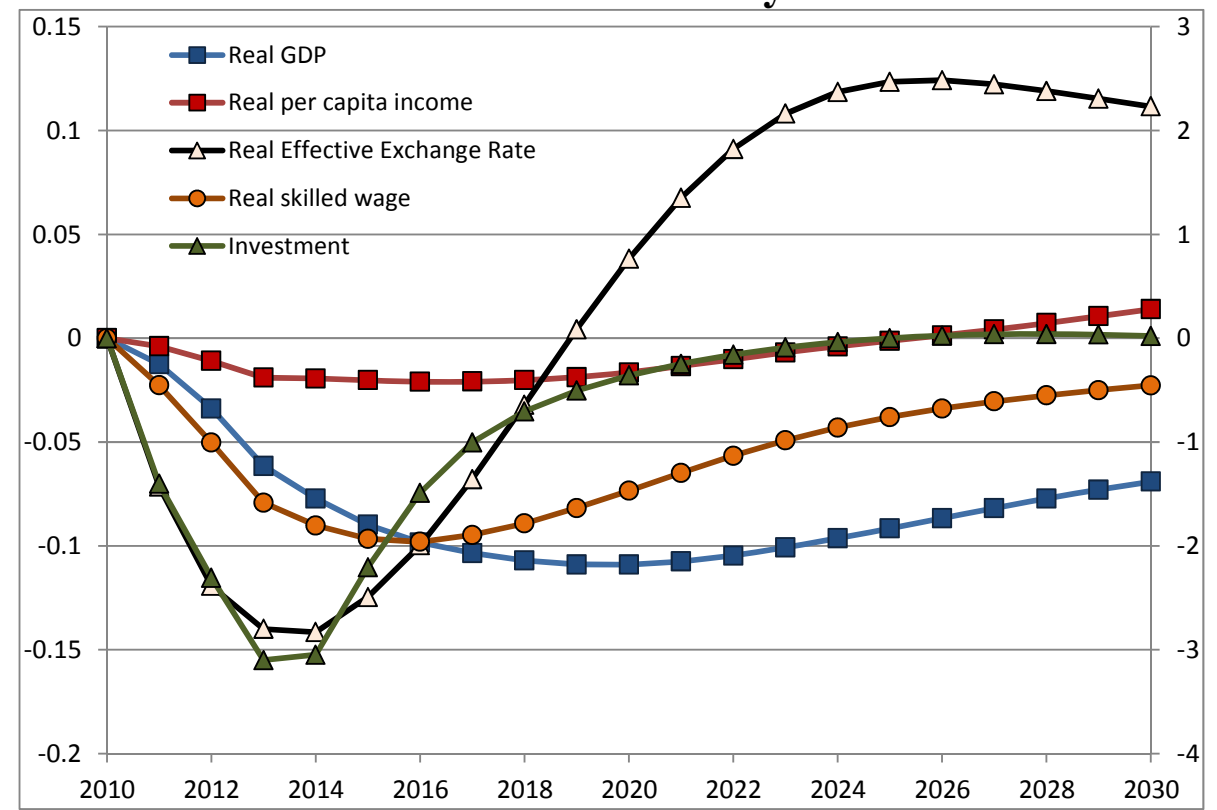

a Here a once and for all one per cent rise in the saving rate is imposed in 2011. Although the saving rate is endogenous, this is achieved using a shock to consumption parameters equation. The graph shows the subsequent path of the real volume of exports in cumulative per cent deviations from a baseline simulation. These deviations are then elasticities of response. Source: Tyers and Zhang (2011). 


\begin{tabular}{|c|c|c|}
\hline \multicolumn{3}{|c|}{$\begin{array}{l}\text { ECONOMICS DISCUSSION PAPERS } \\
2009\end{array}$} \\
\hline $\begin{array}{l}\text { DP } \\
\text { NUMBER }\end{array}$ & AUTHORS & TITLE \\
\hline 09.01 & Le, A.T. & $\begin{array}{l}\text { ENTRY INTO UNIVERSITY: ARE THE CHILDREN OF } \\
\text { IMMIGRANTS DISADVANTAGED? }\end{array}$ \\
\hline 09.02 & $\mathrm{Wu}, \mathrm{Y}$. & CHINA'S CAPITAL STOCK SERIES BY REGION AND SECTOR \\
\hline 09.03 & Chen, M.H. & $\begin{array}{l}\text { UNDERSTANDING WORLD COMMODITY PRICES RETURNS, } \\
\text { VOLATILITY AND DIVERSIFACATION }\end{array}$ \\
\hline 09.04 & Velagic, R. & UWA DISCUSSION PAPERS IN ECONOMICS: THE FIRST 650 \\
\hline 09.05 & McLure, M. & $\begin{array}{l}\text { ROYALTIES FOR REGIONS: ACCOUNTABILITY AND } \\
\text { SUSTAINABILITY }\end{array}$ \\
\hline 09.06 & Chen, A. and Groenewold, N. & $\begin{array}{l}\text { REDUCING REGIONAL DISPARITIES IN CHINA: AN } \\
\text { EVALUATION OF ALTERNATIVE POLICIES }\end{array}$ \\
\hline 09.07 & Groenewold, N. and Hagger, A. & $\begin{array}{l}\text { THE REGIONAL ECONOMIC EFFECTS OF IMMIGRATION: } \\
\text { SIMULATION RESULTS FROM A SMALL CGE MODEL. }\end{array}$ \\
\hline 09.08 & Clements, K. and Chen, D. & AFFLUENCE AND FOOD: SIMPLE WAY TO INFER INCOMES \\
\hline 09.09 & Clements, K. and Maesepp, M. & A SELF-REFLECTIVE INVERSE DEMAND SYSTEM \\
\hline 09.10 & Jones, C. & $\begin{array}{l}\text { MEASURING WESTERN AUSTRALIAN HOUSE PRICES: } \\
\text { METHODS AND IMPLICATIONS }\end{array}$ \\
\hline 09.11 & Siddique, M.A.B. & $\begin{array}{l}\text { WESTERN AUSTRALIA-JAPAN MINING CO-OPERATION: AN } \\
\text { HISTORICAL OVERVIEW }\end{array}$ \\
\hline 09.12 & Weber, E.J. & $\begin{array}{l}\text { PRE-INDUSTRIAL BIMETALLISM: THE INDEX COIN } \\
\text { HYPTHESIS }\end{array}$ \\
\hline 09.13 & McLure, M. & $\begin{array}{l}\text { PARETO AND PIGOU ON OPHELIMITY, UTILITY AND } \\
\text { WELFARE: IMPLICATIONS FOR PUBLIC FINANCE }\end{array}$ \\
\hline 09.14 & Weber, E.J. & $\begin{array}{l}\text { WILFRED EDWARD GRAHAM SALTER: THE MERITS OF A } \\
\text { CLASSICAL ECONOMIC EDUCATION }\end{array}$ \\
\hline 09.15 & Tyers, R. and Huang, L. & $\begin{array}{l}\text { COMBATING CHINA’S EXPORT CONTRACTION: FISCAL } \\
\text { EXPANSION OR ACCELERATED INDUSTRIAL REFORM }\end{array}$ \\
\hline 09.16 & $\begin{array}{l}\text { Zweifel, P., Plaff, D. and } \\
\text { Kühn, J. }\end{array}$ & $\begin{array}{l}\text { IS REGULATING THE SOLVENCY OF BANKS COUNTER- } \\
\text { PRODUCTIVE? }\end{array}$ \\
\hline 09.17 & Clements, K. & THE PHD CONFERENCE REACHES ADULTHOOD \\
\hline 09.18 & McLure, M. & $\begin{array}{l}\text { THIRTY YEARS OF ECONOMICS: UWA AND THE WA } \\
\text { BRANCH OF THE ECONOMIC SOCIETY FROM } 1963 \text { TO } 1992\end{array}$ \\
\hline 09.19 & Harris, R.G. and Robertson, P. & $\begin{array}{l}\text { TRADE, WAGES AND SKILL ACCUMULATION IN THE } \\
\text { EMERGING GIANTS }\end{array}$ \\
\hline 09.20 & $\begin{array}{l}\text { Peng, J., Cui, J., Qin, F. and } \\
\text { Groenewold, N. }\end{array}$ & STOCK PRICES AND THE MACRO ECONOMY IN CHINA \\
\hline 09.21 & Chen, A. and Groenewold, N. & $\begin{array}{l}\text { REGIONAL EQUALITY AND NATIONAL DEVELOPMENT IN } \\
\text { CHINA: IS THERE A TRADE-OFF? }\end{array}$ \\
\hline
\end{tabular}


ECONOMICS DISCUSSION PAPERS

2010

\begin{tabular}{|c|c|c|}
\hline $\begin{array}{l}\text { DP } \\
\text { NUMBER }\end{array}$ & AUTHORS & TITLE \\
\hline 10.01 & Hendry, D.F. & $\begin{array}{l}\text { RESEARCH AND THE ACADEMIC: A TALE OF } \\
\text { TWO CULTURES }\end{array}$ \\
\hline 10.02 & McLure, M., Turkington, D. and Weber, E.J. & A CONVERSATION WITH ARNOLD ZELLNER \\
\hline 10.03 & $\begin{array}{l}\text { Butler, D.J., Burbank, V.K. and } \\
\text { Chisholm, J.S. }\end{array}$ & $\begin{array}{l}\text { THE FRAMES BEHIND THE GAMES: PLAYER'S } \\
\text { PERCEPTIONS OF PRISONER'S DILEMMA, } \\
\text { CHICKEN, DICTATOR, AND ULTIMATUM GAMES }\end{array}$ \\
\hline 10.04 & Harris, R.G., Robertson, P.E. and Xu, J.Y. & $\begin{array}{l}\text { THE INTERNATIONAL EFFECTS OF CHINA'S } \\
\text { GROWTH, TRADE AND EDUCATION BOOMS }\end{array}$ \\
\hline 10.05 & Clements, K.W., Mongey, S. and Si, J. & $\begin{array}{l}\text { THE DYNAMICS OF NEW RESOURCE PROJECTS } \\
\text { A PROGRESS REPORT }\end{array}$ \\
\hline 10.06 & Costello, G., Fraser, P. and Groenewold, N. & $\begin{array}{l}\text { HOUSE PRICES, NON-FUNDAMENTAL } \\
\text { COMPONENTS AND INTERSTATE SPILLOVERS: } \\
\text { THE AUSTRALIAN EXPERIENCE }\end{array}$ \\
\hline 10.07 & Clements, K. & $\begin{array}{l}\text { REPORT OF THE } 2009 \text { PHD CONFERENCE IN } \\
\text { ECONOMICS AND BUSINESS }\end{array}$ \\
\hline 10.08 & Robertson, P.E. & $\begin{array}{l}\text { INVESTMENT LED GROWTH IN INDIA: HINDU } \\
\text { FACT OR MYTHOLOGY? }\end{array}$ \\
\hline 10.09 & Fu, D., Wu, Y. and Tang, Y. & $\begin{array}{l}\text { THE EFFECTS OF OWNERSHIP STRUCTURE AND } \\
\text { INDUSTRY CHARACTERISTICS ON EXPORT } \\
\text { PERFORMANCE }\end{array}$ \\
\hline 10.10 & Wu, Y. & $\begin{array}{l}\text { INNOVATION AND ECONOMIC GROWTH IN } \\
\text { CHINA }\end{array}$ \\
\hline 10.11 & Stephens, B.J. & $\begin{array}{l}\text { THE DETERMINANTS OF LABOUR FORCE } \\
\text { STATUS AMONG INDIGENOUS AUSTRALIANS }\end{array}$ \\
\hline 10.12 & Davies, M. & $\begin{array}{l}\text { FINANCING THE BURRA BURRA MINES, SOUTH } \\
\text { AUSTRALIA: LIQUIDITY PROBLEMS AND } \\
\text { RESOLUTIONS }\end{array}$ \\
\hline 10.13 & Tyers, R. and Zhang, Y. & APPRECIATING THE RENMINBI \\
\hline 10.14 & Clements, K.W., Lan, Y. and Seah, S.P. & $\begin{array}{l}\text { THE BIG MAC INDEX TWO DECADES ON } \\
\text { AN EVALUATION OF BURGERNOMICS }\end{array}$ \\
\hline 10.15 & Robertson, P.E. and Xu, J.Y. & $\begin{array}{l}\text { IN CHINA’S WAKE: } \\
\text { HAS ASIA GAINED FROM CHINA’S GROWTH? }\end{array}$ \\
\hline 10.16 & Clements, K.W. and Izan, H.Y. & $\begin{array}{l}\text { THE PAY PARITY MATRIX: A TOOL FOR } \\
\text { ANALYSING THE STRUCTURE OF PAY }\end{array}$ \\
\hline 10.17 & Gao, G. & WORLD FOOD DEMAND \\
\hline 10.18 & Wu, Y. & $\begin{array}{l}\text { INDIGENOUS INNOVATION IN CHINA: } \\
\text { IMPLICATIONS FOR SUSTAINABLE GROWTH }\end{array}$ \\
\hline 10.19 & Robertson, P.E. & DECIPHERING THE HINDU GROWTH EPIC \\
\hline 10.20 & Stevens, G. & $\begin{array}{l}\text { RESERVE BANK OF AUSTRALIA-THE ROLE OF } \\
\text { FINANCE }\end{array}$ \\
\hline 10.21 & Widmer, P.K., Zweifel, P. and Farsi, M. & $\begin{array}{l}\text { ACCOUNTING FOR HETEROGENEITY IN THE } \\
\text { MEASUREMENT OF HOSPITAL PERFORMANCE }\end{array}$ \\
\hline 10.22 & McLure, M. & $\begin{array}{l}\text { ASSESSMENTS OF A. C. PIGOU’S FELLOWSHIP } \\
\text { THESES }\end{array}$ \\
\hline
\end{tabular}




\begin{tabular}{|l|l|l|}
\hline 10.23 & Poon, A.R. & $\begin{array}{l}\text { THE ECONOMICS OF NONLINEAR PRICING: } \\
\text { EVIDENCE FROM AIRFARES AND GROCERY } \\
\text { PRICES }\end{array}$ \\
\hline 10.24 & Halperin, D. & $\begin{array}{l}\text { FORECASTING METALS RETURNS: A BAYESIAN } \\
\text { DECISION THEORETIC APPROACH }\end{array}$ \\
\hline 10.25 & Clements, K.W. and Si. J. & $\begin{array}{l}\text { THE INVESTMENT PROJECT PIPELINE: COST } \\
\text { ESCALATION, LEAD-TIME, SUCCESS, FAILURE } \\
\text { AND SPEED }\end{array}$ \\
\hline 10.26 & Chen, A., Groenewold, N. and Hagger, A.J. & $\begin{array}{l}\text { THE REGIONAL ECONOMIC EFFECTS OF A } \\
\text { REDUCTION IN CARBON EMISSIONS }\end{array}$ \\
\hline 10.27 & $\begin{array}{l}\text { Siddique, A., Selvanathan, E.A. and } \\
\text { Selvanathan, S. }\end{array}$ & $\begin{array}{l}\text { REMITTANCES AND ECONOMIC GROWTH: } \\
\text { EMPIRICAL EVIDENCE FROM BANGLADESH, } \\
\text { INDIA AND SRI LANKA }\end{array}$ \\
\hline
\end{tabular}


ECONOMICS DISCUSSION PAPERS

\begin{tabular}{|c|c|c|}
\hline \multicolumn{3}{|c|}{2011} \\
\hline $\begin{array}{l}\text { DP } \\
\text { NUMBER }\end{array}$ & AUTHORS & TITLE \\
\hline 11.01 & Robertson, P.E. & $\begin{array}{l}\text { DEEP IMPACT: CHINA AND THE WORLD } \\
\text { ECONOMY }\end{array}$ \\
\hline 11.02 & Kang, C. and Lee, S.H. & $\begin{array}{l}\text { BEING KNOWLEDGEABLE OR SOCIABLE? } \\
\text { DIFFERENCES IN RELATIVE IMPORTANCE OF } \\
\text { COGNITIVE AND NON-COGNITIVE SKILLS }\end{array}$ \\
\hline 11.03 & Turkington, D. & DIFFERENT CONCEPTS OF MATRIX CALCULUS \\
\hline 11.04 & Golley, J. and Tyers, R. & $\begin{array}{l}\text { CONTRASTING GIANTS: DEMOGRAPHIC CHANGE } \\
\text { AND ECONOMIC PERFORMANCE IN CHINA AND } \\
\text { INDIA }\end{array}$ \\
\hline 11.05 & Collins, J., Baer, B. and Weber, E.J. & $\begin{array}{l}\text { ECONOMIC GROWTH AND EVOLUTION: } \\
\text { PARENTAL PREFERENCE FOR QUALITY AND } \\
\text { QUANTITY OF OFFSPRING }\end{array}$ \\
\hline 11.06 & Turkington, D. & $\begin{array}{l}\text { ON THE DIFFERENTIATION OF THE LOG } \\
\text { LIKELIHOOD FUNCTION USING MATRIX } \\
\text { CALCULUS }\end{array}$ \\
\hline 11.07 & Groenewold, N. and Paterson, J.E.H. & $\begin{array}{l}\text { STOCK PRICES AND EXCHANGE RATES IN } \\
\text { AUSTRALIA: ARE COMMODITY PRICES THE } \\
\text { MISSING LINK? }\end{array}$ \\
\hline 11.08 & Chen, A. and Groenewold, N. & $\begin{array}{l}\text { REDUCING REGIONAL DISPARITIES IN CHINA: IS } \\
\text { INVESTMENT ALLOCATION POLICY EFFECTIVE? }\end{array}$ \\
\hline 11.09 & Williams, A., Birch, E. and Hancock, P. & $\begin{array}{l}\text { THE IMPACT OF ON-LINE LECTURE RECORDINGS } \\
\text { ON STUDENT PERFORMANCE }\end{array}$ \\
\hline 11.10 & Pawley, J. and Weber, E.J. & $\begin{array}{l}\text { INVESTMENT AND TECHNICAL PROGRESS IN THE } \\
\text { G7 COUNTRIES AND AUSTRALIA }\end{array}$ \\
\hline 11.11 & Tyers, R. & $\begin{array}{l}\text { AN ELEMENTAL MACROECONOMIC MODEL FOR } \\
\text { APPLIED ANALYSIS AT UNDERGRADUATE LEVEL }\end{array}$ \\
\hline 11.12 & Clements, K.W. and Gao, G. & QUALITY, QUANTITY, SPENDING AND PRICES \\
\hline 11.13 & Tyers, R. and Zhang, Y. & $\begin{array}{l}\text { JAPAN'S ECONOMIC RECOVERY: INSIGHTS FROM } \\
\text { MULTI-REGION DYNAMICS }\end{array}$ \\
\hline 11.14 & McLure, M. & A. C. PIGOU'S REJECTION OF PARETO’S LAW \\
\hline 11.15 & Kristoffersen, I. & $\begin{array}{l}\text { THE SUBJECTIVE WELLBEING SCALE: HOW } \\
\text { REASONABLE IS THE CARDINALITY } \\
\text { ASSUMPTION? }\end{array}$ \\
\hline 11.16 & Clements, K.W., Izan, H.Y. and Lan, Y. & VOLATILITY AND STOCK PRICE INDEXES \\
\hline 11.17 & Parkinson, $\mathrm{M}$. & $\begin{array}{l}\text { SHANN MEMORIAL LECTURE 2011: SUSTAINABLE } \\
\text { WELLBEING - AN ECONOMIC FUTURE FOR } \\
\text { AUSTRALIA }\end{array}$ \\
\hline 11.18 & Chen, A. and Groenewold, N. & $\begin{array}{l}\text { THE NATIONAL AND REGIONAL EFFECTS OF } \\
\text { FISCAL DECENTRALISATION IN CHINA }\end{array}$ \\
\hline 11.19 & Tyers, R. and Corbett, J. & $\begin{array}{l}\text { JAPAN'S ECONOMIC SLOWDOWN AND ITS } \\
\text { GLOBAL IMPLICATIONS: A REVIEW OF THE } \\
\text { ECONOMIC MODELLING }\end{array}$ \\
\hline 11.20 & Wu, Y. & $\begin{array}{l}\text { GAS MARKET INTEGRATION: GLOBAL TRENDS } \\
\text { AND IMPLICATIONS FOR THE EAS REGION }\end{array}$ \\
\hline 11.21 & Fu, D., Wu, Y. and Tang, Y. & $\begin{array}{l}\text { DOES INNOVATION MATTER FOR CHINESE HIGH- } \\
\text { TECH EXPORTS? A FIRM-LEVEL ANALYSIS }\end{array}$ \\
\hline
\end{tabular}




\begin{tabular}{|l|l|l|}
\hline 11.22 & Fu, D. and Wu, Y. & $\begin{array}{l}\text { EXPORT WAGE PREMIUM IN CHINA'S } \\
\text { MANUFACTURING SECTOR: A FIRM LEVEL } \\
\text { ANALYSIS }\end{array}$ \\
\hline 11.23 & Li, B. and Zhang, J. & $\begin{array}{l}\text { SUBSIDIES IN AN ECONOMY WITH ENDOGENOUS } \\
\text { CYCLES OVER NEOCLASSICAL INVESTMENT AND } \\
\text { NEO-SCHUMPETERIAN INNOVATION REGIMES }\end{array}$ \\
\hline 11.24 & Krey, B., Widmer, P.K. and Zweifel, P. & $\begin{array}{l}\text { EFFICIENT PROVISION OF ELECTRICITY FOR THE } \\
\text { UNITED STATES AND SWITZERLAND }\end{array}$ \\
\hline 11.25 & Wu, Y. & $\begin{array}{l}\text { ENERGY INTENSITY AND ITS DETERMINANTS IN } \\
\text { CHINA'S REGIONAL ECONOMIES }\end{array}$ \\
\hline & & \\
\hline
\end{tabular}

